\title{
Discipline or Disruption? Stakeholder Relationships and the Effect of Takeover Threat ${ }^{*}$
}

\author{
Ling Cen \\ University of Toronto \\ Sudipto Dasgupta \\ Lancaster University and Hong Kong University of Science and Technology \\ Rik Sen \\ Hong Kong University of Science and Technology
}

\begin{abstract}
While a sizable literature suggests that firms benefit from vulnerability to takeovers because it reduces agency problems, the threat of takeovers can also impose ex ante costs on firms by adversely affecting relationships with important stakeholders, such as major customers. We find that when firms have corporate customers as important stakeholders, an exogenous reduction in the threat of takeovers increases their ability to attract new customers and strengthens their relationships with existing customers, resulting in improvement in operating performance. The positive effect on operating performance is greater for suppliers that are likely to offer unique and durable products to their customers. Our results suggest a beneficial aspect of protection from takeovers when stakeholder relationships are important.
\end{abstract}

Key words: takeovers, corporate governance, product market relationships, Business Combination Laws

JEL codes: G34, G38, L14

\footnotetext{
${ }^{*}$ We thank Yakov Amihud, Jean-Noel Barrot (discussant at EFA 2014), Shreedhar Bharath, Lauren Cohen, Martijn Cremers, Tom Chemmanur, Xavier Giroud, Michael Hertzel, Vijay Jog (discussant at NFA 2010), Kai Li, David Matsa (discussant at WFA 2010), Michael Lemmon, Ron Masulis (discussant at AsianFA 2010), Ernst Maug, Poonam Mehra (discussant at IGIDR EMF conference 2012), Holger Mueller, Jiaren Pan (discussant at the CICF 2011), Nagpurnanand Prabhala, Uday Rajan, Anjan Thakor, David Yermack, seminar participants at Arizona State University, HEC Montréal, Peking University, Univeristy of Cincinnati, University of Massachusetts, University of Miami, University of New South Wales, the University of Queensland, and Wilfrid Laurier University, conference participants at WFA 2010, NFA 2010, the Asian FA 2010, CICF 2011, EMF 2012, and EFA 2014 for helpful comments and suggestions. Any errors are our own.
} 


\section{Introduction}

An extensive literature suggests that an active takeover market is an important mechanism for reducing managerial slack and improving firm performance (e.g., Grossman and Hart 1980, Jensen 1986, Gompers et al. 2003, Bebchuk et al. 2009, Bertrand and Mullainathan 2003). In this paper, we argue and provide evidence that the threat of takeovers can also impose ex ante costs on firms that have important stakeholders.

The intuition is as follows. Takeovers are disruptive to relationships between firms and their stakeholders. Therefore, ex ante, a higher threat of takeover makes a stakeholder more reluctant to enter into a relationship with a firm and to commit to relationship-specific investments. This adversely affects the firm as it has greater difficulty in attracting high-quality stakeholders. This paper focuses on the stakeholders that are the firm's principal customers, i.e., corporate customers that account for at least $10 \%$ of sales or are important for the firm's business. ${ }^{1}$

Ample informal evidence exists that the risk of disruption caused by the takeover of a supplier is an important concern for customers. For example, in 2010, Dow Jones launched a new information service called Supplier \& Risk Monitor. ${ }^{2}$ This service aims to provide managers with "monitoring of the events affecting suppliers and supply chains" and "help them better manage risk and identify potentially disruptive events." ${ }^{3}$ Ten categories of potential risks to the supply chain are considered, of which Acquisitions and Mergers is one (Bankruptcy and Management Moves are the other corporate events among the ten categories).

\footnotetext{
${ }^{1}$ The importance of stakeholder relationships and how implicit commitments to such relationships can be valuable have been discussed previously by Titman (1984), Shleifer and Summers (1988), and Cremers et al. (2008) and in a contemporaneous paper by Johnson et al. (2014).

${ }^{2}$ LexisNexis recently launched a similar information product, SmartWatch.

${ }^{3}$ According to Brigitte Ricou-Bellan, vice president and managing director of Enterprise Solutions, Dow Jones, "Dow Jones Supplier \& Risk Monitor helps manage the often overwhelming and fragmented flow of information related to key suppliers, providing supply chain managers with critical information that can help them better manage risk and identify potentially disruptive events before they lead to full-blown supply chain disasters, such as product recalls or loss of revenue." (http://www.dowjones.com/pressroom/releases/2010/10192010-DJSRM-0071.asp)
} 
A specific example of a customer's concern about supply-chain disruption is the U.K.-based WPP Group's 1989 takeover attempt of the Ogilvy Group, one of the world's largest advertising companies. ${ }^{4}$ Ogilvy's clients included major companies (principal customers) such as American Express, Unilever, Seagram, and Ford Motor. Several of its clients reacted very negatively to the announcement of the takeover bid. For example, Edgar Bronfman Jr., executive vice president of Seagram's United States operations, called the offer "very unwelcome" and added that a takeover would lead to "tremendous disruption". Nancy Muller, a spokesperson for American Express, said "advertising is a personal service business, and anything that might affect the level of service we receive or the creative output of the agency would be a matter of great concern for us." 56

A decrease in the threat of takeovers can lead to two offsetting effects on firm performance. The first is a negative effect arising from greater managerial slack in response to a drop in the possibility of being punished through a takeover (hereafter, the discipline effect). This effect has been extensively discussed in the literature (e.g., Bertrand and Mullainathan 2003). Our main hypothesis is that a reduction in threat of takeovers also has a beneficial effect on supplier firms with principal customers. Because the likelihood that a takeover would disrupt a customer-supplier relationship is reduced, the supplier firm would find it easier to establish, maintain, and develop relationships with customers, leading to better performance (hereafter, the disruption effect). To show this empirically, we exploit exogenous changes to the threat of takeovers due to the passage of Business Combination (BC) Laws in 30 states in the U.S. between 1985 and 1991. Such changes in law are less likely to be affected by endogeneity concerns, unlike antitakeover protections chosen by individual firms, which could reflect and anticipate those

\footnotetext{
${ }^{4}$ In Section A of our online appendix, we discuss several other examples in detail.

${ }^{5}$ These quotes are taken from an article entitled "The Media Business" published in the New York Times on May 2, 1989.

${ }^{6}$ Microsoft has an arrangement in place with graphics and mobile processor manufacturer Nvidia that gives it the exclusive right to equal any offers by third parties for $30 \%$ or more of Nvidia's outstanding shares. The deal effectively prevents any other company besides Microsoft from acquiring Nvidia. According to an article entitled "Microsoft Pact with Nvidia Could Result in Future Takeover" published in Digital Trends on June 3, 2011, "Having the option to prevent another company acquiring Nvidia puts Microsoft in a strong position as it means the computer giant can stop another company coming along and potentially disrupting the supply chain for components for its devices, such as upcoming tablets running Windows 8 "

(http://www.digitaltrends.com/computing/microsoft-pact-with-nvidia-could-result-in-future-takeover/).
} 
performance changes that we intend to study. ${ }^{7}$ As has been discussed extensively in the literature (see, for example, Bertrand and Mullainathan 2003), BC Laws empower the target boards with the right to refuse certain transactions that make it easier for the acquiring firm to pay back the debt incurred for the acquisition. This enables the target boards to resist hostile takeovers.

We find empirical results supportive of our conjecture. On the one hand, for firms with no principal customers, as suggested by Bertrand and Mullainathan (2003), BC Laws lead to a decrease of return on assets (ROA) of 1.5 percentage points (due to the discipline effect). On the other hand, we find that $\mathrm{BC}$ Laws lead to an increase in ROA of 1.1 percentage points for firms that have principal customers, relative to their non-supplier peers (the disruption effect). This positive effect, on average, offsets over two-thirds of the negative effect from the discipline effect of takeovers and leads to a net effect of $\mathrm{BC}$ Laws that is statistically indistinguishable from zero for firms with principal customers. Our results further suggest that the disruption effect would dominate the discipline effect for firms that have a very large fraction of their sales purchased by principal customers. Because BC Laws affect only the firms that are incorporated in the state that passed the law and only one-third of the firms from our dependent supplier sample are located in their state of incorporation, we are able to control for shocks at the level of state of location. We also control for industry-level shocks while examining the effect of BC Laws on firm performance.

Customers are likely to be especially concerned about potential disruption caused by the takeover of a supplier when the product in question is customized to their requirements or when they have to make specific investments (such as adapting their production processes to a particular type of input being supplied). In general, firms that supply to principal customers typically provide products that are

\footnotetext{
${ }^{7}$ Similar empirical strategies have been used by Bertrand and Mullainathan (1999, 2003), Garvey and Hanka (1999), Cheng et al. (2005), Rauh (2006), Yun (2009), Giroud and Mueller (2010), and Francis et al. (2009). Drawing on the study of the political economy of antitakeover law passage by Romano (1987), Bertrand and Mullainathan (2003) argue that the passage of antitakeover state laws are exogenous to the performance of firms incorporated in those states, with the possible exception of one or two large firms because these laws were typically passed in response to lobbying by one or two large firms that came under attack from a raider. The supplier firms in our sample for which we wish to identify the beneficial effects of BC Laws are typically small firms and are unlikely to have been instrumental in influencing these laws.
} 
customized to the requirements of the customer, as opposed to selling standardized products to a large number of customers. Moreover, customers buying products from research and development (R\&D)intensive suppliers or buying durable products are especially likely to be vulnerable to the threat of takeover of suppliers. ${ }^{8}$ In support of this, we find that the disruption effect of BC Laws on ROA is higher for suppliers with high R\&D expenses and those in durable goods industries.

We investigate the channels through which the reduced likelihood of relationship disruption, due to a decrease in takeover threat, affects performance of firms with principal customers. We find that the passage of a BC Law in the state of incorporation of firms that have corporate principal customers leads to a decrease in selling, general, and administrative (SG\&A) expenses as a proportion of sales, relative to firms with no principal customers. Benchmark-adjusted stock returns of firms with principal customer firms relative to other firms also increase after the announcement of passage of a BC Law. We also find that the passage of a BC Law leads to an increase in the number of corporate principal customers and in the proportion of total sales of the supplier to principal customers. Further, we find that BC Laws lead to stronger relationships between a supplier and its existing corporate principal customers. In particular, a reduction in threat of takeover leads to a longer relationship with principal customers. A BC Law affecting the supplier firm leads to greater sensitivity of that supplier's investment to that of its corporate customer and, similarly, a greater sensitivity of the supplier's operating performance to that of its corporate customer. This increase in co-movement suggests that there is greater outsourcing of some of the production to the supplier after the passage of a BC Law.

One way a supplier could benefit from a BC Law is that the customer would favor it over other suppliers that are in states that did not pass BC Laws. Our data allow us to test this possibility by

\footnotetext{
${ }^{8}$ This is because products supplied by R\&D-intensive suppliers are likely to be specifically designed and difficult to replace. Meanwhile, durable goods typically require after-sales support from the supplier. As an example of the importance of after-sales service for customers of durable goods, consider the recent wave of consolidations in the high-tech industry, driven by firms such as Oracle, IBM, and Hewlett-Packard. An Associated Press article published on July 5, 2010 ("Tech Customers Skeptical of Takeovers" by Jordan Robertson) documents how customers are poorly served when their suppliers are acquired. One customer who replaced DEC servers with machines from IBM and Sun Microsystems when DEC was acquired by Compaq states: "I have never seen a merger that saves the customer money." He went on to say that he "learned to try to pick computing suppliers that aren't likely to be acquired."
} 
identifying a sample of two competing suppliers of the same principal customer, in which one supplier's state passes a BC Law and the other supplier's state does not do so in the prior and subsequent three years. This sample is necessarily small because we want to ensure that the suppliers come from the same four-digit standard industrial classification (SIC) code, so as to be almost certain that they are head-tohead competitors supplying similar products to their common principal customer. We find that while the supplier incorporated in a law-change state experiences higher sales growth and ROA after a BC Law, its competing supplier experiences a decrease in sales growth and ROA, relative to industry benchmarks, over the three years after the BC Law.

Overall, we find that higher threat of takeovers can adversely affect firm performance because it prevents the firm from committing to long-term relationships with stakeholders. Some studies seem to indirectly suggest that shareholders always prefer greater vulnerability to hostile takeovers (see, e.g., Gompers et al. 2003, Bebchuk et al. 2009). Our results imply that this might not be the case, especially for firms for which long-term stakeholders are important, e.g., firms with a very high fraction of sales to principal customers. Cremers et al. (2008) find evidence that firms seem to be trading off costs and benefits of takeover defenses and choosing an optimum level. While they do not provide direct evidence of the cost of being exposed to the market for corporate control, they "speculate that ... takeovers can be disruptive to a target firm's existing suppliers, customers, and employees, especially in long-term relationships." Our results provide direct evidence of such costs of being exposed to takeovers. In contemporaneous work, Johnson et al. (2014) find that firms adopt more takeover defenses at the initial public offering (IPO) stage if they have more important customers and suppliers. Moreover, the customer firms experience more positive stock price reactions at the IPO stage if the suppliers adopt antitakeover provisions. These studies focus on the choices made by firms about their takeover protection and complement our findings about the benefits of being insulated from takeovers. ${ }^{9}$ Our study employs an exogenous change in takeover protection to show that being exposed to takeovers is beneficial to some

\footnotetext{
${ }^{9}$ Bates et al. (2008) suggest other benefits of antitakeover provisions: They endow target managers with leverage sufficient to deter opportunistic bidding, negotiate for higher value bids, and pursue higher-value third-party suitors.
} 
firms that have important stakeholders. Further, we explore in depth the nature and magnitude of some of these benefits.

\section{How Can Takeover Protection Be Beneficial to Firms with Important Customers?}

Shleifer and Summers (1988) were among the first to argue that takeovers - especially hostile ones—can impose ex ante costs on a firm's shareholders because they adversely affect the incentives of important stakeholders to make specific investments in their relationship with the firm. Shleifer and Summers argue that such takeovers are usually motivated by the possibility of ex post wealth redistribution in favor of shareholders, for example, through layoffs, renegotiation of wage contracts, or asset sales. However, these actions also reduce the incentives of stakeholders such as employees to acquire specific skills that are not valuable outside the firm. Shleifer and Summers (1988) argue that firms can prosper only if the "implicit contracts" with employees and other stakeholders are not reneged, even though such a breach can increase shareholder value ex post. ${ }^{10}$

One context in which the arguments of Shleifer and Summers are particularly plausible is when a firm depends on a few principal customers for its sales. These principal customers are among the most important stakeholders for such a firm. For several reasons, the acquisition of a supplier could be disruptive to the relationship with the firm's principal customers and impose costs on those customers. The presence of these costs associated with takeover's adverse impact on the incentive of important stakeholders implies that takeover protection of the supplier will enable it to attract more business from its principal customers.

In Section A of our online appendix, we discuss in detail why the acquisition of a supplier could be disruptive to the relationships with the firm's principal customers and impose costs on those customers, and provide several examples and anecdotal evidence. Here, we briefly summarize these arguments.

\footnotetext{
${ }^{10}$ Schnitzer (1995) formalizes these kinds of arguments and models them in the context of managerial incentives. Related to our arguments, Johnson et al. (2014) maintain that takeover defenses can prevent opportunistic behavior toward a firm's important stakeholders.
} 


\subsection{Acquirer Debt and Debt-Financed Acquisitions}

Most acquisitions that are paid in cash involve a significant increase in the acquirer's debt. The takeover boom of the 1980s (the period during which most of the state-level Business Combination Laws were passed) saw many acquisitions financed with debt. During periods of industry consolidation, serial acquirers often emerge with high levels of debt. Acquirers burdened with takeover debt are undesirable from the point of view of a customer of the target because they might go into financial distress, cut quality, and let go of key employees, all of which affect the customer adversely. Kale and Shahrur (2007) and Banerjee et al. (2008) examine the dynamics between debt financing and customer-supplier relationships. In addition to academic studies, substantial anecdotal evidence shows that debt-financed takeovers are a concern for customers, as we discuss in Section A.1 of our online appendix.

\subsection{Horizontal Market Power and Consolidation}

An acquirer may be interested in a particular supplier to increase its monopsony power vis-à-vis upstream firms or to compete more effectively with other suppliers. This is clearly costly for the customer, not only because it can result in the customer paying higher prices for the products, but also because it eliminates competition for its suppliers and creates scope for slack.

A related issue arises when an acquirer attempts to buy suppliers with the specific objectives of overhauling and consolidating product lines. Oracle's pursuit of consumer relationship management (CRM) product suppliers, such as PeopleSoft and Siebel, was motivated by a desire to consolidate the functionalities of various products into one application. However, PeopleSoft's and Siebel's customers were strongly opposed to the move as they had already invested in a particular system and were concerned about losing support. A principal customer who has invested in a particular product from a supplier is at risk if the latter's acquisition is driven by the desire to replace the existing product with an improved version that has a broader range of functionalities, as the switching costs may be substantial.

\subsection{Other Acquisition Motives}

Motives for an acquisition could be unrelated to the principal customer. For example, an undervalued supplier without adequate takeover protection could be an attractive takeover target. In such a case, the 
acquisition could impose costs on the principal customer if the integration of the supplier with the acquirer is inefficient. For example, the acquisition could be associated with replacement or departure of employees who are crucial to the relationship with the principal customer or with other inefficiencies that arise when an independent entity is integrated into a much larger one. Even though such transitions impose costs on the principal customer, the customer may not be able to switch if it has already invested in the relationship (e.g., designed its production process to the input provided by the supplier).

A principal customer is particularly vulnerable if an acquirer is mainly interested in aspects of the supplier's business that do not involve the principal customer. Thus, an acquirer may decide to acquire a supplier to exploit a specific synergy, for example, access to specific markets, co-branding of certain products, or a particular know-how. However, such an acquisition may not be in the interest of a principal customer who relies on the supplier for a very specialized product.

The acquisition could also be driven by the acquirer's need to grow rapidly or acquire assets quickly to fill orders from its own customers. In such cases, given capacity constraints, its own requirements may take priority over those of the supplier's customers, leading to delays in delivery or deterioration of quality of the input supplied to the principal customer. In Section A.2 of our online appendix, we discuss Flextronics' acquisition of Dovatron, as an example of an acquirer being more interested in the supplier's other business than that with the existing customer (Beckman Coulter, in this case). ${ }^{11}$

\section{Data}

Our main data source is Standard and Poor's Compustat. Our sample consists of all firms that are not regulated utility firms (i.e., industries 31 and 48 in the Fama and French 48 industry classification) and are located and incorporated within the U.S. The start of our sample period is 1979, which is the earliest year for which information about principal customers is available. As in Bertrand and Mullainathan

\footnotetext{
${ }^{11}$ The dispute between the customer and the acquirer in this case resulted in the largest jury verdict in a civil dispute in Orange County (California) history.
} 
(2003) and Giroud and Mueller (2010), our sample period ends in $1995 .{ }^{12}$ We exclude firms for which the book value of assets is missing or negative. We also drop firms for which the state of location or incorporation is not available from Compustat. This leaves 13,092 firms and 100,496 firm-year observations in our sample.

The Statement of Financial Accounting Standards No. 14 (SFAS 14, issued in 1976 and superseded by SFAS 131 in 1997) of the Financial Accounting Standards Board (FASB) requires firms to disclose the existence of and sales to their principal customers. ${ }^{13}$ Principal customers are those who account for more than $10 \%$ of the total revenue of the firm or are considered important for business. Because noncorporate customers, such as governments, nonprofit entities, and individuals, may not be driven by profit maximization motives, the arguments we make as to why customers care about threat of disruption may not hold for them. Therefore, we focus on identifying firms that supply to corporate principal customers. ${ }^{14}$ These data are obtained from Compustat's segment customer files. For some of the tests, we need to obtain financial information about the principal customers. However, the database reports the name of the customer without identifiers. Often only an abbreviated version of the name is reported, and the same customer is reported in a different form in different years and by different suppliers. Sometimes, the disclosed customer name is a subsidiary or a business segment of a firm. We manually match the customer to Compustat. ${ }^{15}$ Those principal customers that we are able to match to Compustat, we refer to as identified principal customers.

Table 1 shows the mean and median values of some characteristics for all sample firms, supplier firms (i.e., firms that reported at least one principal customer), and customer firms that are in Compustat (i.e., Compustat firms whose name is reported as a principal customer by at least one firm). The median customer firm is larger, is older, and has a higher return on assets than the median firm in Compustat. The

\footnotetext{
${ }^{12}$ The last state that passed BC Laws in our sample is Oklahoma in 1991.

${ }^{13}$ After 1997, SFAS 131 requires the disclosure of the existence of principal customers that account for more than $10 \%$ of a firm's total sales. However, the disclosure of principal customers' identities is voluntary.

${ }_{11}^{14}$ Throughout the paper, the term "principal customer" refers to corporate principal customers.

${ }^{15}$ When customer names are disclosed in relationship pairs, we are able to match $68.7 \%$ of principal customer firms to GVKEYs in Compustat.
} 
median supplier firm is smaller and slightly younger than the median firm in Compustat. The ROA of the median supplier firms is comparable to that of a median Compustat firm. The median supplier firm obtains one-quarter of its revenues from principal customers. This suggests that principal customers are important from suppliers' perspective.

\section{[Insert Table 1 Near Here]}

Table 2 shows the number of firms that are incorporated and located in each state. The firm's state of location is defined as the state in which its headquarters is located. The state of incorporation determines the legal jurisdiction that applies to the firm. A state's Business Combination Laws apply to firms incorporated in that state. We find that about $61 \%$ of the supplier firms are located outside their states of incorporation. This allows us to examine the effects of BC Laws, which operate at the level of the state of incorporation, while controlling for shocks at the level of state of location.

$$
\text { [Insert Table } 2 \text { Near Here] }
$$

\section{Empirical Analysis}

\subsection{Primary Empirical Methodology}

Our empirical strategy relies on the exogeneity of the change in takeover threat due to the passage of Business Combination Laws in 30 states between 1985 and 1991. These laws reduce the threat of a hostile takeover for firms that are incorporated in a state that passes such a law. ${ }^{16}$ Romano (1987), Bertrand and Mullainathan (2003), and Karpoff and Wittry (2014) mention that a small number of large firms actively lobbied for BC Laws. Replicating a paper by Atanassov (2013) in a setting very similar to ours, Karpoff and Wittry (2014) find that 25 firms (associated with 356 firm-years in Atanassov's sample) were involved. Given the small number of large-size motivating firms, and the fact that supplier firms for

\footnotetext{
${ }^{16}$ These laws not only affect those takeover attempts that are overtly hostile, but also affect takeovers that would seem friendly, but the management would not oppose knowing that such an action would lead to the acquirer pursuing the takeover in a hostile fashion. In Table B4 of our online appendix, we show that BC Laws reduce the likelihood of being a target of hostile as well as friendly takeovers.
} 
which we wish to identify the positive effect of BC Laws are typically much smaller firms, the endogeneity of BC Laws to lobbying is not likely to be a major issue for our identification.

The years in which states in the U.S. passed BC Laws are reported in Table 2. Given that the passages of state-level BC Laws are key events in our setting, a firm's state of incorporation before the passage of BC Laws is the most important information in our tests. A major challenge for our study (and, as far as we are aware, for every other study using the passage of BC Laws as a quasi-natural experiment) is that Compustat provides information only for a firm's most recent state of incorporation. Using this information to determine whether the firm should be considered as a treated firm (as is typically done) presents two types of problems. First, because many firms change their states of incorporation after our sample period (1995-2014), the classification of the state of incorporation at and around the law change is incorrect. Second, some firms may change their states of incorporation to one (or out of one) that has recently passed BC Laws, thereby violating the exogeneity of treatment. We find that a nontrivial number of firms ( 671 or $5 \%$ of our sample firms) change their states of incorporation from 1979 to $1995 .{ }^{17}$

To address these issues, in all our tests, we consider a firm as treated at time $t$ ' if the state where it was incorporated at the time this firm enters our sample passed a BC Law at time $t$ (i.e., $\mathrm{t}^{\prime}>\mathrm{t}$ ). In other words, firms that were incorporated in New York when they enter the sample will be considered as treated after 1985 when New York passed a BC Law. This helps us get around the concern that using the actual state of incorporation after the passage of a BC Law in a state might pick up a selected set of firms that endogenously choose to reincorporate in New York right after 1985. For example, these firms could do so in anticipation of having more business from principal customers in the future. Using a treatment dummy that excludes these latter firms as treated in 1985 is similar to an intent-to-treat approach. ${ }^{18}$

\footnotetext{
${ }^{17}$ To identify these firms, we first examine whether the state of incorporation in Mergent Online differs from that in Compustat. If this is the case, we manually search Mergent Online to determine when and where the firm reincorporated.

${ }^{18}$ Another way of thinking about this is that the timing of BC Law passage in the state of incorporation when firms enter the sample is taken as an instrument for the actual treatment dummy. Because most firms do not change their state of incorporation in the sample period, this instrument is strong. Meanwhile, all our tests are robust if we define the BC Law dummy (i.e., the firms that are treated) based on the time-varying actual state of incorporation at year $t$.
} 
In our first set of empirical tests, which provides the basic structure for many of the later tests, we examine whether BC Laws have different effects on the performance of firms with principal customers, relative to benchmark firms with no principal customers. We estimate the following model for all firms in our sample:

$$
\begin{aligned}
& \text { Performance }_{\mathrm{ijst}}= \\
& \alpha_{\mathrm{i}}+\alpha_{\mathrm{jt}}+\alpha_{\mathrm{st}}+\beta \text { PC Dummy }_{\mathrm{it}}+ \\
& \\
& \gamma \text { PC Dummy } \\
& \text { PCAfter_BC_Law } \\
& \\
& \phi \text { After_BC_Law } \text { Pat }_{\mathrm{it}}+\boldsymbol{\delta}^{\prime} \text { Controls }_{\mathrm{it}}+\varepsilon_{\mathrm{it}}
\end{aligned}
$$

where $i$ indexes firms, $j$ indexes industry, $s$ indexes the state of location, and $t$ indexes time. $\alpha_{\mathrm{i}}, \alpha_{\mathrm{jt}}$, and $\alpha_{\mathrm{st}}$ are firm, industry-year, and state-year fixed effects, respectively. The standard errors in our estimations are clustered at the state of incorporation level. ${ }^{19}$

The dependent variable in Equation (1) is a measure of operating performance: return on assets (ROA), which is defined as EBITDA (earnings before interest, taxes, depreciation, and amortization) divided by book value of total assets. Like Giroud and Mueller (2010), we drop observations that are at the extreme $1 \%$ tails of ROA values to remove the impact of outliers. PC Dummy is a dummy variable that equals one if the firm has at least one principal customer and zero otherwise. After_BC_Law is a dummy variable that equals one if the state in which the firm was incorporated at the time it enters our sample had passed a BC Law by time $t$ and zero otherwise. We include size and firm age as additional control variables. Size is defined as the natural logarithm of total assets, and Age is the natural logarithm of one plus the number of years the firm has been included in Compustat.

Only about one-third of the firms are incorporated in their state of location, allowing us to control for shocks at the level of state of location while examining the effect of BC Law on firm performance. We control for industry and local shocks by including industry-year (Fama and French 48 industries) and state-year fixed effects, respectively. Some researchers have included the average of the dependent

\footnotetext{
${ }^{19}$ This allows for potential correlation between error terms of the same firm over time, as well as across different firms incorporated in the same state. As shown in Table B7 of our online appendix, the statistical significance of our main results is not affected if standard errors are clustered only by firm.
} 
variable for each industry-year and state-year to achieve the same objective. Gormley and Matsa (2014) show that such a specification gives inconsistent estimates, which can potentially be severely biased. Therefore, we estimate a model with separate fixed effects for every industry-year combination and every state-year combination..$^{20}$ Because there are a large number of fixed effects in three different dimensions, it is not computationally feasible to estimate this in the form of an OLS regression by including the dummy variables. The model is estimated using an iterative procedure. ${ }^{21}$

The coefficient $\phi$ captures the effect of BC Laws on firms that do not have any principal customers, and $\gamma$ captures the additional effect on firms with principal customers relative to firms with no principal customers. Based on our discussions above, $\phi$ represents the effect of BC Laws due to reduction in discipline and $\gamma$ represents the effect of BC Laws due to reduction in disruption. Because the discipline effect has been extensively discussed in the literature, $\gamma$ is the coefficient of our primary interest. ${ }^{22}$

In specification (1), the firm fixed effects control for fixed differences across firms, which subsume any fixed differences between firms in the treated group and the control group. ${ }^{23}$ The treatment group is the set of firms that are incorporated in states (at the time they enter our sample) in which a BC Law has been passed. The control group contains all firms incorporated in states that have not passed a BC Law until time $t$. Thus, firms incorporated in states that have never passed a BC Law are always part of the control group. In addition, firms that are incorporated in a state that did pass a BC Law will be part of the control group for the period prior to the passage of the BC Law.

A specification estimating the coefficient on After_BC_Law in the presence of the controls in Equation (1) would, in essence, be a difference-in-difference estimate of the effect of BC Law. It would capture the differential change in performance of the treatment group firms due to BC Law, relative to the

\footnotetext{
${ }^{20}$ Controlling for the average of the dependent variable at the state-year and industry-year level, instead of including fixed effects, gives very similar results in this context.

${ }^{21}$ We use the REGHDFE procedure in STATA. The document titled "Explanation of the HDFE Iteration with 3 FEs," by Sergio Correia, the author of this command, explains the details of the iterative procedure. It is available at http://fmwww.bc.edu/repec/bocode/r/reghdfe_explanation.pdf.

${ }^{22} \beta$ captures the relationship between having a principal customer and firm performance. It is not possible to interpret it as capturing a causal relationship.

${ }^{23}$ Firm fixed effects also subsume differences between antitakeover provisions between the treatment and the control group, as these are very persistent.
} 
change in performance of the control group firms over the same period. This would be $\phi$ in the following regression specification:

$$
\begin{aligned}
& \text { Performance }_{i t}= \\
& \quad \alpha_{i}+\alpha_{t}+\phi \text { After_BC_Law }{ }_{i t}+\delta^{\prime} \text { Controls }_{i t}+\varepsilon_{i t} .
\end{aligned}
$$

By comparison, the specification in Equation (1) is equivalent to a triple-difference approach, in which the coefficient $\gamma$ captures whether the law has a differential effect on performance of firms with principal customers, relative to firms with no principal customers.

We also employ other specifications similar to that in Equation (1). In particular, we replace the dummy variables capturing the presence of a principal customer with the continuous variable $P C$ Percentage, which is defined as the ratio of sales to principal customer to the total sales of the firm.

\subsection{Effect of an Exogenous Reduction in Takeover Threat on Firm Profitability}

The results presented in Table 3 show the effect of BC Laws on performance of different types of firms. Column (1) shows the results of a base-case regression specification given in Equation (2). Consistent with Bertrand and Mullainathan (2003) and Giroud and Mueller (2010), we find that BC Laws have an adverse effect on the performance of the average firm in the sample. Column (2) shows the result of estimating the regression specification given in Equation (1). We find that, relative to firms with no principal customers, the ROA of firms with principal customers increases by 1.1 percentage points as a result of BC Laws. Because the coefficient of After_BC_Law in column (2) is -1.5 percentage points, on average, the positive effect through the disruption channel offsets more than two-thirds of the negative effect through the discipline channel. The net effect of BC Laws on the ROA of firms with principal customers, as captured by the sum of the coefficient for After_BC_Law (-0.015) and the coefficient for After_BC_Law $\times$ PC Dummy (0.011), is not significantly different from zero $(t$-statistic $=-0.92)$.

$$
\text { [Insert Table } 3 \text { Near Here] }
$$

To test the robustness of these results, we replace the dummy variables that capture the presence of principal customers with continuous variables representing the proportion of sales to such customers. 
The results for this specification are presented in column (3) of Table 3. Paralleling the results based on dummy variables, BC Laws have a larger positive and more statistically significant effect on the performance of firms for which sales to principal customers are more important. ${ }^{24}$ From coefficients in column (3), it follows that when the percentage sales to principal customers are larger than $46.7 \%$, the effect through the disruption channel would dominate the effect through the discipline channel and the net effect of BC Laws on the ROA of supplier firms is positive.

Columns (4) and (5) show the results analogous to columns (2) and (3), after replacing $P C$ Dummy with Id PC Dummy, which represents that the firm has a principal customer that exists in the Compustat database. We show these results because some of our later tests require information about the principal customer. For those tests, we recognize a supplier-customer relationship only when both firms are included in the Compustat. This slight change in definition makes no difference to the results.

We also find that controlling for the following variables makes no difference to our results: leverage, cash holdings, tangibility of assets, volatility of daily stock returns, and the interaction between After_BC_Law and Herfindahl-Hirshman Index (HHI) of the industry [capturing the possibility that the effect of BC Laws on firm performance can vary by competitiveness of the industry, as shown in Giroud and Mueller (2010)]. These results are reported in Table B1 of our online appendix.

\subsection{Interaction with Product Uniqueness}

The possibility of disruption of the relationship is likely to be of a greater concern to the customer if the supplier's product requires after-sales support or is unique and specifically produced for the customer. Firms in durable goods industries are more likely to be producing unique products that require after-sales support in the form of servicing and maintenance (Titman and Wessels 1988). Therefore, we expect that the effect of a reduction in takeover threat on performance would be stronger for dependent suppliers in durable goods industries relative to those in nondurable industries. Column (1) of Table 4 studies this effect. A firm is defined as producing a durable good if it is in an industry that is classified as a durable

\footnotetext{
${ }^{24}$ The coefficient on PC Dummy is positive and significant. Although, in our setup, it is not possible to interpret this coefficient causally, this result is consistent with the finding in Patatoukas (2012) that greater fraction of sales to principal customers is associated with better firm performance.
} 
goods industry by Gomes et al. (2009). The effect of BC Laws on the ROA of nondurable firms with principal customers, relative to nondurable firms without principal customers, is an increase of 1.0 percentage points. There is an additional increase of 2.1 percentage points for durable firms with principal customers, relative to nondurable supplier firms.

\section{[Insert Table 4 Near Here]}

Suppliers that have a high R\&D intensity are likely to produce goods for their customers that are unique and not easily producible by some other firms, making them indispensable for the customers. Column (2) of Table 4 shows that the effect of reduction in takeover threat is higher for supplier firms with a higher R\&D intensity. There is an additional increase in ROA of 1.5 percentage points due to BC Laws among high $R \& D$ firms with principal customer, relative to high $R \& D$ firms without principal customers. This suggests that the impact of a reduction in takeover threat is higher when the importance of a long-term relationship is greater, i.e., when the supplier offers a durable or a unique product.

\subsection{Examining the Sources of Improvement in Performance}

To provide further support for our hypothesis and to better understand the effect of BC Laws through the disruption channel on the performance of suppliers with principal customers, we explore the effect of BC Laws on other firm-level variables of performance. $R O A$, which is our main measure of performance, can be decomposed as follows:

$$
\begin{aligned}
& \text { ROA }=\text { EBITDA } / \text { Assets }=(\text { Sales }- \text { Costs }) / \text { Assets } \\
& =(\text { Sales/Assets })[1-\text { COGS/Sales }- \text { SG\&A/Sales }- \text { Other Costs/Sales }] \ldots
\end{aligned}
$$

One possibility is that the improvement in performance of suppliers, relative to their non-supplier peers, is a result of an increase in orders from corporate principal customers, leading to higher sales as a proportion of assets. Alternatively, stronger relationships can also lead to better cost-efficiency driven by economies of scale for the supplier firm. This can lower the cost of goods sold, as well as SG\&A expenses, as a proportion of sales.

We run regressions similar to that in Equation (1), in which the dependent variable is sales scaled by total assets. The coefficient of After_BC_Law in column (1) suggests that the BC Laws lead to a 
reduction of 2.6 percentage points of Sales/Assets for firms with no principal customers. Although statistically insignificant, the coefficient of After_BC_Law $\times$ PC Dummy shows that for suppliers with principal customers, the ratio of sales to total assets goes up by a 1.5 percentage points due to BC Laws relative to their non-supplier peer firms.

To test if the improvement in firm performance documented earlier is partly driven by reduction in costs, we run a regression similar to that in Equation (1), with the left-hand-side variables being cost of goods sold scaled by sales (COGS/Sales) and selling, general, and administrative expenses scaled by sales (SGA/Sales). Columns (3) and (5) of Table 5 show that, for firms without principal customers, the BC Laws lead to an increase of 1.5 percentage points in COGS/Sales and 2.3 percentage points in SGA/Sales. This result is consistent with Bertrand and Mullainathan (2003). Although statistically insignificant, COGS/Sales of firms with principal customers goes down by 1.3 percentage points relative to these nonsupplier firms, which almost eliminates the increase of COGS/Sales in the baseline non-supplier firms. $S G A /$ Sales goes down by 1.6 percentage points relative to these non-supplier firms, and this effect is statistically significant at the $5 \%$ level. The results are similar when we use fraction of sales to principal customers instead of the dummy variable for the existence of a principal customer. This suggests that BC Laws lead to higher sales as well as better cost-efficiency for firms with corporate principal customers.

\section{[Insert Table 5 Near Here]}

We next examine whether a reduction in takeover threat due to BC Laws leads to an increase in the ability of the firm to attract more business from principal customers. We do this by examining the effect of BC Laws on the number of principal customers and the fraction of sales of the supplier firm to its principal customers. These results are shown in Table 6. We estimate a specification similar to Equation (2) for all firms in our sample with the dependent variable replaced by the number of principal customers and the fraction of sales to principal customers. ${ }^{25}$ To define the dependent variable, we

\footnotetext{
${ }^{25}$ We estimate OLS because our specification has a large number of fixed effects. It is widely understood that, in a large class of nonlinear panel data models, the coefficient estimates using maximum likelihood estimation are biased and inconsistent. This is often referred to as the incidental parameters problem. (See Wooldridge (2010, page 495 and page 692) and Greene (2004) for more details.) However, a Poisson model with firm fixed effects estimated
} 
consider only those principal customers that account for more than $10 \%$ of the sales so that a change in voluntary disclosure of customers below the $10 \%$ cutoff does not affect the results. These results are presented in Table 6.

\section{[Insert Table 6 Near Here]}

We see a significant increase in the number of principal customers as well as the proportion of total sales to principal customers as a result of BC Laws. Column (1) shows that BC Laws lead to an increase in the number of principal customers by 0.056 . Because the average number of principal customers accounting for more than $10 \%$ of sales is 0.61 , this represents a $9.2 \%$ increase in number of principal customers due to BC Laws. Columns (2) and (3) show that the fraction of sales to principal customers in suppliers' total sales goes up as a result of BC Laws, both at the firm level (i.e., sales to all principal customers aggregated at the supplier's firm level) and at the customer-supplier relationship level. These results support our hypothesis that BC Laws help firms acquire new principal customers and obtain more business from existing principal customers.

Overall, our results so far suggest that a reduction in the takeover probability of the supplier allows it to obtain more business from principal customers, resulting in an improvement in its ROA relative to non-supplier firms. This relative improvement seems mainly driven by a decrease in the proportion of administrative costs to total sales.

\subsection{Firm-Level Antitakeover Provisions and Other Robustness Issues}

\subsubsection{Antitakeover Provisions}

Karpoff and Wittry (2014, p. 12) argue that "firm-level defenses are substitutes for state antitakeover laws in their provision of antitakeover protection." ${ }^{26}$ This raises the issue of why firms would not already be at

using a quasi-maximum likelihood procedure does not suffer from this problem. We find that a Poisson model for a number of principal customers gives similar results to the ones reported. The results are in Table B2 in our online appendix. While estimating this model, we cluster standard errors by firm. A Poisson model assumes equality of conditional variance and conditional mean of the dependent variable. Therefore, it underestimates standard errors if the data exhibit over-dispersion, i.e., the conditional variance is greater than the conditional mean, as is often observed in many contexts. Clustering standard errors breaks the link between the coefficient estimates and standard errors in the model, which helps deal with this problem.

${ }^{26}$ We also thank the editor and an anonymous referee for urging us to discuss this issue. 
the optimal level of takeover protection and why there should be any incremental effect of antitakeover laws. However, Karpoff and Wittry (2014) also convincingly argue that several large firms actively lobbied for antitakeover laws, which suggests that, even for large firms, firm-level takeover defenses do not necessarily provide the desired level of takeover protection and are probably not easy to change.

An analysis of the costs and benefits of adopting additional firm-level takeover defenses is beyond the scope of this paper. However, to examine whether possible rigidities or adjustment costs associated with firm-level antitakeover provisions modify the impact of BC Law adoption (consistent with the substitution hypothesis) on firm performance, we exploit the industry-level clustering of antitakeover provisions documented by Johnson et al. (2009). We construct the variable ATP Abs Change, which is the industry mean of the annualized absolute change in the Governance Index (G-Index) due to firm-level provisions (i.e., excluding those determined by the state of incorporation) for the Fama and French 48 industry to which the firm belongs. Intuitively, a higher level of ATP Abs Change proxies for a lower level of adjustment cost associated with firm-level antitakeover provisions. Information about firmlevel antitakeover provisions, which is retrieved from the Investor Responsibility Research Center (IRRC) Corporate Takeover Defenses database, is available for the period between 1990 and 2006 and lies largely outside our sample period. ${ }^{27}$ In a regression specification similar to that in Equation (1), we add a threeway interaction term of ATP Abs Change, After_BC_Law, and PC Dummy (or PC Percentage). The results are presented in Table 7. The three-way interaction is significantly negative, suggesting that the BC Law change had a stronger effect for firms in industries that face higher adjustment costs associated with firm-level antitakeover provisions.

\section{[Insert Table 7 Near Here]}

\subsubsection{First- and Second-Generation Antitakeover Laws}

Karpoff and Wittry (2014) point out that some states adopted other antitakeover laws (the so-called firstand second-generation laws) that need to be considered when evaluating the impact of BC Laws. In our

\footnotetext{
${ }^{27}$ To alleviate concern that the prior adoption of BC Laws could affect our ATP Abs Change measure, we examine the correlation of this measure and the industry mean of the After_BC_Law dummy for the years 1990 and 1995. These correlations are insignificantly different from zero.
} 
context, BC Laws are of particular significance from a principal customer's point of view because the major effect of these laws was to make debt-financed acquisition difficult. Principal customers are particularly likely to be wary of takeover threats from acquirers who could end up being highly levered, as the examples in Section A.1 of the online appendix suggest.

Karpoff and Wittry (2014, p.14) argue that "the existence of first-generation antitakeover laws constitutes the most obvious concern ... at least for tests that include data from before 1983." Our sample period begins in 1979. When we drop the years 1979-1983 and re-estimate Equation (1), our results become stronger. ${ }^{28}$ Further, our results still hold if we allow the After BC Law dummy to turn on only for firms incorporated in Delaware (where $46 \%$ of all firms are incorporated in our sample), which passed BC Laws but not first- or second-generation antitakeover laws. ${ }^{29}$

\subsection{The Effect of BC Laws on Competing Suppliers}

All the results presented so far focus on the effect of BC Laws on supplier firms that enjoy lower takeover threat due to passage of the laws. We might also expect the BC Laws to indirectly impact other firmsthose that are not incorporated in the state and are in direct competition with the suppliers impacted by the BC Laws because they supply same or similar goods to a common principal customer.

Previously, we found that BC Laws lead to greater business from principal customers. In general, the increase in business from principal customers could come from three sources:

(1) The supplier gains new business from an existing customer at the expense of another competing supplier that already sells a similar product to the same customer and is located in a state that did not (recently) have a BC Law change. These firms can be identified from our data because they are dependent suppliers of the same customer. Providing evidence for this channel is essentially equivalent to identifying the indirect effect of BC Laws.

(2) The supplier gains at the expense of other potential supplier firms. These firms are not currently supplying to the customer, but they might become suppliers in the future based on new needs of the

\footnotetext{
${ }^{28}$ This result is reported in Table B5 of our online appendix.
}

${ }^{29}$ This result is reported in Table B6 of our online appendix. 
customer. The difference between this channel and (1) is that the potential supplier firms cannot be identified as they are not currently supplying to that customer.

(3) The supplier obtains more business from a principal customer, replacing production that the customer would have done in-house and was reluctant to outsource before the reduction in takeover threat.

Because detecting the second and the third channels is difficult, we confine our attention to channel (1). ${ }^{30}$ We identify customer firms with two suppliers in the same four-digit SIC industry but incorporated in different states. We do not use two-digit or three-digit SIC industry classification here, because a narrow industry definition ensures that these firms are extremely likely to be supplying the same product and competing with each other for the business of their common principal customer. ${ }^{31}$ Let us, for the sake of clarity of exposition, refer to these entities as customer, supplier1, and supplier2. We require that the state of incorporation of supplier1 (state1) passes a BC Law at some point, say, in year $t$. Further, we require that the supplier2's state of incorporation (state2) does not pass a BC Law in a $[t-3$, $t+3$ ] window. When state 1 passes a BC Law, this should have a positive effect on the business it gets from the customer. Our results so far are consistent with this. Our aim is to show that supplier2, whose state of incorporation does not pass a BC Law around the same time, is adversely affected, because the customer is likely to shift business away from it and give it to supplier1.

Our data set does not capture all competing suppliers. Two suppliers could be providing similar products to the same customer, but the customer may not be a principal customer (representing more than $10 \%$ of sales) for one of the suppliers. Further, suppliers may be capable of producing goods and services that are associated with a different SIC code than those they have been classified into. Therefore, we are

\footnotetext{
${ }^{30}$ Our tests in Subsection 4.7, showing the strengthening of the supplier's relationship with its existing customers, are consistent with the third channel.

${ }^{31}$ Two suppliers in the same broad industry might be supplying complementary products. If that were the case, we might expect the opposite of the effect we are looking for here. For example, General Motors (GM) has two longterm dependent suppliers (among many other suppliers): Johnson Controls Inc. (GVKEY $=06268$ ) and Perceptron Inc. $(\mathrm{GVKEY}=25676)$, in 1990s. Johnson Controls Inc. supplies and assembles automobile seating, interiors, and batteries for GM, and it belongs to the SIC4 industry 3822 (auto controls for regulating residential and commercial environment). Perceptron Inc. produces and sells noncontact (i.e., optical) measurement and inspection solutions for automotive body construction, construction of automotive closures, and closure installation and fitting. It belongs to SIC4 industry 3827 (optical instrument and lenses). While these two suppliers belong to the same SIC3 industry (i.e., 382), their products and services are completely different and are more likely complements, to the extent that when GM's demand for one input increases, that for the other is also likely to increase.
} 
unable to obtain a comprehensive sample of competing suppliers to the same customer. Nevertheless, we obtain 156 trios of customer-supplier1-supplier2, with both suppliers in the same industry but incorporated in different states. We then examine the effect of the passage of a BC Law in state1 on the year-on-year change in ROA and growth in sales to the principal customer of supplier1 and supplier2. For benchmarking, we obtain the average change in ROA and the growth rate of sales to their principal customers of all other suppliers in our sample in the same industry as supplier1 and supplier2.

Table 8 shows the average growth rate of sales of supplier1 and supplier2 to their principal customers, as well as the annual change in ROA for three years after the passage of a BC Law in state1. Supplier1 has higher sales growth and change in ROA compared with the benchmark firms in each of the three years following the law change. Supplier2 has negative sales growth and change in ROA relative to the benchmark firms in each of these three years. This shows the negative effect on a competing supplier incorporated in a different state due to a BC Law change. All effects are in the direction predicted, and most of them are statistically significant. As expected, the differences in sales growth between supplier1 and supplier2 are highly statistically significant, as are the differences in change in ROA.

\section{[Insert Table 8 Near Here]}

The above test also helps us address any residual concerns of endogeneity in our main results, arising from the passage of $\mathrm{BC}$ Laws in anticipation of future performance of firms incorporated in a state. We argued earlier that this is unlikely to be a concern in our context, as we focus on supplier firms that are small and played no role in determining the passage of a BC Law. Because the competing suppliers identified for this test are incorporated in a different state, this test is not affected by the above endogeneity concern. It is extremely unlikely that adoption of a BC Law in one state would be in anticipation of future under-performance of firms that are incorporated in a different state.

\subsection{The Effect of Takeover Threat on the Strength of Customer-Supplier Relationships}

A reduction in the probability of a takeover of the supplier should lead to a strengthening of the relationship between the supplier and the customer. We show in Subsection 4.3 that suppliers' sales to principal customers increase after the probability of a takeover is reduced. That result is based on firm- 
level data in which one supplier's sales to all principal customers have been aggregated. In this subsection, by focusing on relationship-level data, we provide further evidence that the customer-supplier relationship is strengthened. For suppliers that have multiple principal customers in the same year, we now treat each of the relationships as a separate observation.

We first construct a panel of relationships in which a supplier-customer-year is used as a unit of observation. When a supplier lists the same customer as a principal customer for at least two consecutive years, we call it a relationship. We examine whether the reduction in takeover threat due to adoption of a BC Law in the supplier's state has an effect on the probability that the relationship will continue. To do this, we estimate a Cox proportional hazards model, in which the failure in the model is defined by an absence of a relationship in years $t+1, t+2$, and $t+3 .{ }^{32}$ Our main explanatory variable of interest is After_BC_Law, which is one if a BC Law has been passed in the current year or any of the previous years in the supplier's state of incorporation. For independent variables in our specifications, we control for the sales to this customer as a proportion of total sales of the supplier and the cost of materials purchased from this supplier as a proportion of the COGS of the customer. We also include ROA and size for both the supplier and the customer as control variables.

Table 9 shows that a BC Law leads to a significant reduction in the probability of relationship termination. The coefficient of After_BC_Law is -0.287 in column (1), which is statistically significant at the $1 \%$ level. This coefficient corresponds to a hazards ratio of 0.750 , which suggests that, after the passage of BC Laws, the probability of relationship termination is $25.0 \%$ lower relative to that before the passage of BC Laws.

\section{[Insert Table 9 Near Here]}

We provide further evidence of relationship strengthening for the subsample of relationships with corporate customers using a different strategy. A closer relationship would likely result in the supplier's undertaking more investments at times when the customer increases its investment. This should result in a

\footnotetext{
${ }^{32}$ This is to ensure that if the customer temporarily does not need the product from its supplier for one or two years, that is not considered as relationship termination. If the relationship resumes in year $t+4$ or later, it would be regarded as a new relationship.
} 
greater co-movement in their investments. Moreover, a stronger relationship should result in greater comovement of the supplier's and customer's performance. For example, greater demand for the customer's products should lead to more orders for the supplier's products from the customer.

We first examine whether the sensitivity of the supplier's investment to that of the customer goes up as a result of BC Law adoption in the supplier's state. We use Capex scaled by total assets as our variable to capture capital investment. Column (1) of Table 10 shows the results for the regression of supplier's investment on customer's investment, an interaction term between customer's investment and a dummy variable representing the passage of a BC Law in supplier's state of incorporation, and other controls. In column (2), we replace the customer's investment by its one-period lagged investment to allow for the possibility that the effect of a shock leading to higher customer investments might not be immediately transmitted to the supplier. For both specifications, the coefficients on the interaction term are economically and statistically significant. For example, the result in column (1) suggests that the contemporaneous co-movement in Capex between customers and suppliers increases by 158\% (0.095 / 0.060) after the passage of BC Laws and the effect is statistically significant at the $1 \%$ level. We argue that the increased sensitivity of the supplier's investment to the customer's investment after the adoption of a BC Law implies higher outsourcing from the customer to the supplier.

[Insert Table 10 Near Here]

The economic and statistical significance of the interaction term could pick up a general or mechanical effect of an increasing co-movement or lead-lag between a large firm and a small firm or between any firms in the customer industry and firms in the supplier industry. We adopt a placebo simulation test to rule out this possibility. We replace the actual customer firm in a relationship pair by a randomly chosen firm in its own industry (i.e., Fama and French 48 industries) and size quintile. We name this randomly picked firm the placebo customer firm, and we generate a simulated sample based on placebo customer firms. We repeat this procedure 1,000 times, and then we are able to generate 1,000 sets of coefficients from simulated samples based on the same regression specifications as we did in the true sample. Between the supplier firm and the placebo customer firm, we only break down the actual 
customer-supplier relationship. However, the industry-related and size-related firm characteristics of the actual customer are maintained by the placebo customer firm. Therefore, if our results are driven by economic dynamics at the industry level or any diffusion of economic activities from large-size firms to small-size firms, we expect to see no difference between the coefficient from the true sample and those coefficients generated from simulated samples based on placebo customer firms. Put differently, if we do see that the coefficient from the true sample is larger or smaller than most coefficients from simulated samples, this difference can be attributed only to the economic mechanism through the customer-supplier relationship between the actual customer and the actual supplier.

For example, the 1,000 coefficients of Customer Capex/TA $\times$ After_BC_law from simulated samples in column (1) of Table 10 have a mean of 0.008 and a standard deviation of 0.040 . With the distribution of these 1,000 coefficients, we can find out where the value of the coefficient with respect to the actual customer firms lies in this distribution. We find that the coefficient based on actual customers (0.095) is larger than $97.7 \%$ of 1,000 coefficients based on placebo customers. This suggests that our effect is unlikely to be explained by potentially increasing co-movement between firms in supplier industries and firms in customer industries or between large-size firms and small-size firms.

Similarly, we test the sensitivity of a supplier's ROA to contemporaneous and lagged ROA of the customer. The results presented in columns (3) and (4) of Table 10 show that the ROA sensitivity also goes up significantly after the passage of a BC Law.

Overall, we find strong evidence that $\mathrm{BC}$ Laws result in a reduction in takeover threat to the supplier, leading to an increase in the strength of the customer-supplier relationship. This is reflected in a greater probability that the relationship will continue, a greater sensitivity of the supplier's investment to that of its customer, and a greater sensitivity of the supplier's performance to that of its customers.

\subsection{The Effect of a Takeover (or a Takeover Attempt) on Relationship Continuation}

Our arguments as to why takeover protection can have beneficial effects on suppliers with principal customers require that takeovers can be disruptive to the customers. We provide anecdotal evidence in the Introduction, outline the channels through which such disruption can occur in Section 2, and provide 
examples in Section A of our online appendix. In this subsection, we provide empirical support for this link in the argument by examining the effect of a takeover (or a takeover attempt) of the supplier on the probability of continuing a relationship with an existing customer.

Table 11 shows the effect of a takeover or a takeover attempt of the supplier on the continuation of a customer-supplier relationship for another year (or another two years). ${ }^{33}$ A relationship with a principal customer is considered to be discontinued only if the supplier firm is covered by Compustat even after the event, but it no longer reports this principal customer. This ensures that a firm's dropping out of the database or consolidating in financial statement reporting with the acquirer is not considered a discontinuation of a relationship. For the purpose of this test, we define takeover as cases in which the acquirer has less than $50 \%$ ownership of the target firm before the deal and aims to hold more than $50 \%$ after the deal. The main independent variables of interest are whether the supplier was successfully taken over in a particular year and whether there was an unsuccessful takeover attempt of the supplier. We define success and failure with respect to the original intentions of the acquirer. Information about mergers and acquisitions is obtained from the Securities Data Company (SDC) Platinum database.

$$
\text { [Insert Table } 11 \text { Near Here] }
$$

We estimate the impact of a takeover or a takeover attempt on the likelihood of relationship continuation by a probit model. The dependent variables, Cont $1 Y$ and Cont $2 Y$, are dummy variables that equal one if the relationship still continues in the following year and two years, respectively. The acquisition could be triggered by worsening sales to principal customers, which, in turn, can have an effect on the likelihood of continuing a relationship with the customer in the future. Therefore, we include an additional control variable: the growth rate of sales to principal customers in the past year. Contrary to

\footnotetext{
${ }^{33} \mathrm{We}$ examine the effects of all takeovers, including those that are not classified as hostile by the SDC database. We do this for two reasons. First, the SDC database classification tends to miss out on identifying numerous takeovers as hostile, which were not hostile at deal completion although they started out as such. Second, BC Laws affect not just those takeover attempts that are overtly hostile, but also takeovers that would seem friendly, but the management would not oppose knowing that such an action would lead to the acquirer pursuing the takeover in a hostile fashion. In Table B4 of our online appendix, we show that BC Laws significantly reduce the likelihood of takeover attempts that were classified as hostile by SDC as well as those that were not.
} 
the above concern, we observe that sales to principal customers tend to rise, not fall, in the year before a takeover.

We find that a successful takeover of the supplier reduces the probability of relationship continuation into the next year by about 17.8 percentage points and the probability of the relationship continuing two more years by about 20.1 percentage points. Both effects are statistically significantly at the $1 \%$ level. An unsuccessful takeover attempt reduces the probability of the relationship continuation into the next year by about 6.9 percentage points, although the effect is statistically insignificant.

A merger deal could use cash, stock, or a mix of the two. Because cash deals are more likely to be financed using debt, they would increase the bankruptcy risk of the supplier, making the relationship less attractive from the customer's perspective. We might therefore expect a lower probability of relationship continuation for deals financed by cash than those financed by stock. Columns (2) and (4) of Table 10 show that this is the case, for successful as well as unsuccessful takeover attempts. The probability of relationship continuation is lower if a higher fraction of the deal is financed using cash. These results provide support for the hypothesis that a takeover of a supplier is likely to disrupt its relationship with a customer.

\subsection{The Effect of BC Laws on the Stock Return Differentials between Suppliers and Non-Suppliers}

In previous subsections, we showed the effect of BC Laws on operating performance and we suggested that the improvement in operating performance for firms with principal customers relative to peers without principal customers is driven by increased sales and reduced costs in transactions with principal customers. In this subsection, we examine the effect of BC Laws on firm value.

We do not choose to rely on the traditional measure of firm value, Tobin's Q, in our test. The reason is that, if the suppliers increase investment in response to the adoption of BC Laws, the market-tobook could fall, even though firm value is higher. ${ }^{34}$ In Table B3 of our online appendix, we do find that, in a setting similar to that of our main tests, supplier growth rate in book value of total assets does

\footnotetext{
${ }^{34}$ Section $\mathrm{C}$ of our online appendix provides a numerical example.
} 
increase significantly after the passage of a BC Law in the original state of incorporation. For this reason, we study the effect of BC Laws on the stock return differentials between suppliers and non-suppliers.

Following Giroud and Mueller (2010), we incorporate all 19 states where the announcement dates and the effective dates of BC Laws can be identified. Consistent with the result in Table 10 of Giroud and Mueller (2010), we also find that stock returns of firms incorporated in the states that passed BC Laws are on average negative around the announcement dates. However, we do not observe a significant return differential between suppliers and non-suppliers. Our conjecture is that it is not as easy for investors to immediately distinguish the disruptive effect of mergers and acquisitions on firms with important stakeholder relationships from the discipline effect for all firms. Therefore, we focus on stock returns over a longer period after the announcement of BC Laws in our test.

\section{[Insert Table 12 Near Here]}

For each announcement, we include stock returns of both firms incorporated in the state where the announcement is made and firms in states where there are no BC Law changes six months before and after the announcement date. Stock returns of all firms are computed in three time horizons: a period from the announcement date to the effective date of the BC Law, a three-month period after the announcement date, and a six-month period after the announcement date. ${ }^{35}$ The raw returns are adjusted by benchmark portfolio returns based on Fama and French 48 industry, size, and book-to-market ratio.

The effect of BC Law passage on the long-term stock returns after the announcements is similar to that on operating performance. For example, in a six-month horizon, stock returns of non-supplier firms incorporated in the state that just passed the BC Law are lower than stock returns of their peers incorporated outside this state by 2.2 percentage points. However, there exists a return differential of 2.4 percentage points between suppliers and non-suppliers that are incorporated in the state of law changes. This leads to a net positive (although not statistically significant) effect of BC Laws on stock returns for suppliers incorporated in the states of law changes relative to their peers.

\footnotetext{
${ }^{35}$ The duration between the announcement date and the effective dates of BC Laws varies significantly across states. For example, the duration is longer than one year in Pennsylvania but shorter than one month in Minnesota. Therefore, we complement this horizon by two other horizons with fixed duration.
} 


\section{Conclusion}

Using the passage of Business Combination Laws as a source of exogenous variation, we find that firms that have important relationships with principal customers experience a significant improvement in operating performance, relative to their non-supplier peers, when the threat of a takeover goes down. We show that this effect is driven by the increased number of principal customers, the increased sales to principal customers, and the strengthened relationships with principal customers after the passage of $\mathrm{BC}$ Laws. These empirical results support the hypothesis that the threat of takeovers can impair the ability of firms to commit to long-term relationships with important stakeholders, adversely affecting their profitability and performance. This is consistent with the notion that the threat of takeovers not only can discipline managerial slack, but also can make it more difficult for firms to commit to long-term relationships with other stakeholders due to the possibility of disruption. 


\section{References}

Atanassov J (2013) Do hostile takeovers stifle innovation? Evidence from antitakeover legislation and corporate patenting. J. Finance 68:1097-1131.

Banerjee S, Dasgupta S, Kim Y (2008) Buyer-supplier relationships and the stakeholder theory of capital structure. J. Finance 63:2507-2552.

Bates T, Becher DA, Lemmon ML (2008) Board classification and managerial entrenchment: evidence from the market for corporate control. J. Financial Econom. 87:656-677.

Bebchuk, LA, Cohen A, Ferrell A (2009) What matters in corporate governance? Rev. Financial Stud. $22: 783-827$.

Bertrand M, Mullainathan S (1999) Is there discretion in wage setting? A test using takeover legislation. RAND J. Econom. 30:535-554.

Bertrand M, Mullainathan S (2003) Enjoying the quiet life? Corporate governance and managerial preferences. J. Political Econom. 111:1043-1075.

Cheng S, Nagar V, Rajan MV (2005) Identifying control motives in managerial ownership: Evidence from antitakeover legislation. Rev. Financial Stud. 18:637-672.

Cremers KM, Nair VB, Peyer U (2008) Takeover defenses and competition. J. Empirical Legal Stud. 5:791-818.

Fama EF, French K (1997) Industry costs of equity. J. Financial Econom. 43:153-193.

Francis B, Hasan I, John K, Waisman M (2009) The effect of state antitakeover laws on the firm's bondholders. J. Financial Econom. 96:127-154.

Garvey GT, Hanka G (1999) Capital structure and corporate control: The effect of antitakeover statutes on firm leverage. J. Finance 54:519-546.

Giroud X, Mueller H (2010) Does corporate governance matter in competitive industries? J. Financial Econom. 95:312-331.

Gomes JF, Kogan L, Yogo M (2009) Durability of output and the cross-section of stock returns. $J$. Political Econom. 117:941-986.

Gompers PA, Ishii JL, Metrick A (2003) Corporate governance and equity prices. Quart. J. Econom. 118:107-155.

Gormley TA, Matsa D (2014) Common errors: How to (and not to) control for unobserved heterogeneity. Rev. Financial Stud. 27:617-661.

Greene WH (2004) Fixed effects and bias due to the incidental parameters problem in the Tobit model. Econometric Rev. 23:125-147.

Grossman SJ, Hart OD (1980) Disclosure laws and takeover bids. J. Finance 35:323-334. 
Hannes S (2006) A demand-side theory of antitakeover defenses. J. Legal Stud. 35:475-524.

Jensen MC (1986) Agency costs of free cash flow, corporate finance, and takeovers. Amer. Econom. Rev. 76:323-329.

Johnson WC, Karpoff JM, Yi S (2014) The bonding hypothesis of takeover defenses: Evidence from IPO firms. Working Paper, University of Washington.

Johnson SA, Moorman T, Sorescu S (2009), A reexamination of corporate governance and equity prices. Rev. Financial Stud.22: 4753-4786

Kale J, Shahrur H (2007) Corporate capital structure and the characteristics of suppliers and customers. $J$. Financial Econom. 83:321-365.

Karpoff JM, Wittry MD (2014) Test identification with legal changes: The case of state antitakeover laws. Working Paper, University of Washington

Patatoukas PN (2012) Customer-base concentrations: Implications for firm performance and capital markets. Accounting Rev. 87:363-392.

Rauh JD (2006) Own company stock in defined contribution pension plans: A takeover defense? $J$. Financial Econom. 81:379-410.

Romano R (1987) The political economy of takeover statutes. Virginia Law Rev. 73:111-199.

Schnitzer M (1995) "Breach of trust" in takeovers and the optimal corporate charter. J. Indust. Econom. 43:229-259.

Shleifer A, Summers L (1988) Breach of trust in hostile takeovers. In Auerbach AJ (Ed.), Corporate Takeovers: Causes and Consequences (University of Chicago Press, Chicago, IL).

Titman S (1984) The effect of capital structure on a firm's liquidation decision. J. Financial Econom. $13: 137-151$.

Titman S, Wessels R (1988) The determinants of capital structure choice. J. Finance 43:1-19.

Wooldridge, JM (2010) Econometric Analysis of Cross Section and Panel Data (MIT Press, Cambridge, MA).

Yun H (2009) The choice of corporate liquidity and corporate governance. Rev. Financial Stud. 22:14471475 . 


\section{Table 1 Summary Statistics}

This table reports the mean and median values of several firm characteristics of three samples for the period 1979-1995. The sample reported in column (1) includes all firms in non-regulated industries from the Compustat Fundamental Annual File. The sample reported in column (2) consists of all dependent suppliers that report at least one principal customer. In column (3), the sample includes all principal customer firms that have dependent suppliers. ROA is defined as earning before interest, taxes, depreciation, and amortization (EBITDA) scaled by the book value of total assets; Total Assets is the book value of total assets; History is the number of years that a firm has existed in the Compustat database; Sales/Assets is total sales scaled by the book value of total assets; COGS/Sales is total cost of goods sold scaled by total sales; SGA/Sales is selling, general, and administrative expenses scaled by total sales; and Capex/Assets is capital expenditures scaled by the book value of total assets. We also report the mean and median values of the proportional sales to principal customers for dependent suppliers in columns (2) and proportional inputs from dependent suppliers for principal customers in column (3). ROA, Sales/Assets, COGS/Sales, SGA/Sales, and Capex/Assets are censored at the 1st and 99th percentile values. We require that all firms in these samples have positive book values of total assets and non-missing information about the state of incorporation and the state of location in Compustat.

\begin{tabular}{|c|c|c|c|c|c|c|}
\hline \multirow[b]{2}{*}{ Firm characteristics } & \multicolumn{2}{|c|}{$\begin{array}{l}\text { (1) All Firms } \\
\text { in Compustat }\end{array}$} & \multicolumn{2}{|c|}{$\begin{array}{l}\text { (2) All Dependent } \\
\text { Supplier Firms }\end{array}$} & \multicolumn{2}{|c|}{$\begin{array}{l}\text { (3) All Principal } \\
\text { Customer Firms }\end{array}$} \\
\hline & Mean & Median & Mean & Median & Mean & Median \\
\hline$R O A$ & 0.062 & 0.101 & 0.050 & 0.107 & 0.141 & 0.148 \\
\hline Total Assets (\$M) & 1279.809 & 53.404 & 395.123 & 27.539 & 7383.667 & 1492.784 \\
\hline History (years) & 11.480 & 8.000 & 10.080 & 7.000 & 22.171 & 24.000 \\
\hline Sales/Assets & 1.156 & 1.056 & 1.214 & 1.123 & 1.332 & 1.183 \\
\hline COGS/Sales & 0.688 & 0.672 & 0.703 & 0.681 & 0.665 & 0.702 \\
\hline SGA/Sales & 0.339 & 0.238 & 0.364 & 0.239 & 0.231 & 0.202 \\
\hline Capex/Assets & 0.073 & 0.047 & 0.077 & 0.049 & 0.080 & 0.068 \\
\hline Sales to Principal Customers/Total Sales & & & 0.324 & 0.250 & & \\
\hline Purchases from Dependent Suppliers/COGS & & & & & 0.045 & 0.010 \\
\hline Total number of firms & \multicolumn{2}{|c|}{13,092} & \multicolumn{2}{|c|}{7,302} & \multicolumn{2}{|c|}{1,184} \\
\hline Total number of observations & \multicolumn{2}{|c|}{100,496} & \multicolumn{2}{|c|}{39,197} & \multicolumn{2}{|c|}{5,943} \\
\hline
\end{tabular}




\section{Table 2 States of Incorporation and States of Location}

This table describes the distribution of dependent suppliers and principal customers across states of incorporation and states of location. This table first reports the year when Business Combination Laws were passed in each state. The state of incorporation in our paper is defined as the state where a firm was incorporated at the time this firm enters our sample. Column (1) shows the number of dependent suppliers and principal customers in each state by state of incorporation. Column (2) shows the number of suppliers and customers by state of location, i.e., where a firm's headquarters is located; and column (3) shows the number of dependent suppliers and principal customers that are located in their states of incorporation. Our sample contains all firms in non-regulated industries from the Compustat Fundamental Annual File between 1979 and 1995. We also require that all firms in the sample have positive book values of total assets and non-missing information about the state of incorporation and the state of location in Compustat.

\begin{tabular}{|c|c|c|c|c|c|c|c|}
\hline \multirow[b]{2}{*}{ State } & \multirow{2}{*}{$\begin{array}{c}\text { BC } \\
\text { Laws } \\
\text { passed }\end{array}$} & \multicolumn{2}{|c|}{$\begin{array}{c}\text { (1) Firms Incorporated in } \\
\text { This State }\end{array}$} & \multicolumn{2}{|c|}{$\begin{array}{l}\text { (2) Firms Located in } \\
\text { This State }\end{array}$} & \multicolumn{2}{|c|}{$\begin{array}{l}\text { (3) Firms Incorporated and } \\
\text { Located in This State }\end{array}$} \\
\hline & & Suppliers & Customers & Suppliers & Customers & Suppliers & Customers \\
\hline Alaska & - & 4 & 1 & 4 & 0 & 2 & 0 \\
\hline Alabama & - & 9 & 1 & 31 & 6 & 7 & 0 \\
\hline Arkansas & - & 9 & 6 & 30 & 10 & 5 & 4 \\
\hline Arizona & 1987 & 35 & 2 & 104 & 12 & 28 & 2 \\
\hline California & - & 688 & 105 & 1,300 & 198 & 598 & 93 \\
\hline Colorado & - & 228 & 12 & 268 & 26 & 127 & 5 \\
\hline Connecticut & 1989 & 27 & 5 & 181 & 32 & 24 & 4 \\
\hline D. C. ${ }^{\dagger}$ & - & 5 & 2 & 15 & 3 & 1 & 0 \\
\hline Delaware & 1988 & 3,356 & 600 & 22 & 6 & 17 & 5 \\
\hline Florida & - & 198 & 18 & 378 & 45 & 145 & 17 \\
\hline Georgia & 1988 & 73 & 16 & 179 & 36 & 62 & 14 \\
\hline Hawaii & - & 9 & 1 & 10 & 0 & 7 & 0 \\
\hline Iowa & - & 20 & 6 & 28 & 8 & 13 & 5 \\
\hline Idaho & 1988 & 6 & 0 & 14 & 3 & 4 & 0 \\
\hline Illinois & 1989 & 58 & 8 & 269 & 64 & 43 & 8 \\
\hline Indiana & 1986 & 55 & 13 & 74 & 14 & 39 & 6 \\
\hline Kansas & 1989 & 19 & 4 & 38 & 4 & 14 & 1 \\
\hline Kentucky & 1987 & 11 & 3 & 37 & 7 & 10 & 2 \\
\hline Louisiana & - & 18 & 0 & 37 & 3 & 13 & 0 \\
\hline Massachusetts & 1989 & 202 & 36 & 386 & 64 & 166 & 30 \\
\hline Maryland & 1989 & 95 & 21 & 123 & 20 & 38 & 10 \\
\hline Maine & 1988 & 8 & 2 & 8 & 1 & 5 & 1 \\
\hline Michigan & 1989 & 90 & 19 & 142 & 27 & 73 & 13 \\
\hline Minnesota & 1987 & 222 & 25 & 241 & 36 & 178 & 22 \\
\hline Missouri & 1986 & 38 & 9 & 94 & 26 & 28 & 7 \\
\hline Mississippi & - & 6 & 1 & 19 & 2 & 6 & 1 \\
\hline
\end{tabular}




\begin{tabular}{lccccccc} 
Montana & - & 4 & 0 & 7 & 0 & 4 & 0 \\
North Carolina & - & 50 & 4 & 119 & 21 & 44 & 4 \\
North Dakota & - & 5 & 0 & 3 & 0 & 2 & 0 \\
Nebraska & 1988 & 6 & 1 & 19 & 3 & 5 & 1 \\
New Hampshire & - & 5 & 0 & 33 & 4 & 2 & 0 \\
New Jersey & 1986 & 171 & 30 & 403 & 61 & 122 & 17 \\
New Mexico & - & 13 & 0 & 18 & 1 & 7 & 0 \\
Nevada & 1991 & 190 & 22 & 57 & 6 & 27 & 6 \\
New York & 1985 & 413 & 58 & 731 & 101 & 273 & 28 \\
Ohio & 1990 & 141 & 40 & 215 & 51 & 114 & 32 \\
Oklahoma & 1991 & 40 & 3 & 88 & 14 & 28 & 3 \\
Oregon & - & 50 & 8 & 63 & 12 & 39 & 7 \\
Pennsylvania & 1989 & 142 & 26 & 261 & 51 & 102 & 20 \\
Rhode Island & 1990 & 10 & 2 & 22 & 5 & 8 & 2 \\
South Carolina & 1988 & 15 & 4 & 34 & 4 & 12 & 4 \\
South Dakota & 1990 & 4 & 1 & 7 & 2 & 3 & 1 \\
Tennessee & 1988 & 27 & 5 & 80 & 18 & 23 & 5 \\
Texas & - & 205 & 23 & 678 & 106 & 179 & 22 \\
Utah & - & 87 & 2 & 77 & 6 & 43 & 1 \\
Virginia & 1988 & 81 & 21 & 155 & 32 & 50 & 12 \\
Vermont & - & 5 & 0 & 11 & 2 & 4 & 0 \\
Washington & 1987 & 72 & 10 & 93 & 16 & 56 & 8 \\
Wisconsin & 1987 & 53 & 8 & 77 & 14 & 46 & 8 \\
West Virginia & - & 5 & 0 & 9 & 1 & 3 & 0 \\
Wyoming & 1989 & 19 & 0 & 10 & 0 & 6 & 0 \\
\hline Total & & 7,302 & 1,184 & 7,302 & 1,184 & 2,855 & 431 \\
\hline D.C. = District of Columbia & & & & & & \\
\hline
\end{tabular}




\section{Table 3 Effect of Business Combination Laws on Operating Performance of Dependent Suppliers}

This table presents the estimates of OLS regressions of operating performance on the interaction between the status of dependent suppliers for principal customers and the passage of Business Combination Laws in suppliers' states of incorporation. Our sample contains all Compustat firms in non-regulated industries for the period between 1979 and 1995. The dependent variable, ROA, is censored at 1 st and 99th percentile values. PC Dummy is a dummy variable that equals one if this firm has at least one principal customer and zero otherwise. Id PC Dummy is a dummy variable that equals one if this firm has at least one principal customer that can be identified by Compustat GVKEY and zero otherwise. When Dummy in these variable names are replaced by Percentage, the dummy variables are replaced by the proportional sales of dependent suppliers' sales to the corresponding type of principal customers. After_BC_Law is a dummy variable that equals one if Business Combination Laws have passed in suppliers' state of incorporation and zero otherwise. Other control variables in all columns are the natural logarithm of book value of total assets (Size) and the natural logarithm of one plus the number of years the firm has been included in Compustat (Age). We control for the firm fixed effects, the state-year fixed effects, and the industry-year fixed effects in all OLS regressions. Industries are defined by the Fama and French 48 industry specification. The standard errors (in parentheses) are clustered at the state of incorporation level. ${ }^{* *},{ }^{* *}$, and $*$ denote statistical significance at the $1 \%$, $5 \%$, and $10 \%$ level, respectively.

\begin{tabular}{|c|c|c|c|c|c|}
\hline Variables & $\begin{array}{c}(1) \\
R O A\end{array}$ & $\begin{array}{c}(2) \\
R O A\end{array}$ & $\begin{array}{c}(3) \\
R O A\end{array}$ & $\begin{array}{c}(4) \\
R O A\end{array}$ & $\begin{array}{c}(5) \\
R O A \\
\end{array}$ \\
\hline After_BC_Law $\times$ PC Dummy & & $\begin{array}{l}0.011^{* *} \\
(0.005)\end{array}$ & & & \\
\hline PC Dummy & & $\begin{array}{l}0.019 * * * \\
(0.003)\end{array}$ & & & \\
\hline After_BC_Law $\times$ PC Percentage & & & $\begin{array}{l}0.030^{* * *} \\
(0.007)\end{array}$ & & \\
\hline PC Percentage & & & $\begin{array}{l}0.062^{* * *} \\
(0.008)\end{array}$ & & \\
\hline After_BC_Law $\times$ Id PC Dummy & & & & $\begin{array}{l}0.012^{* *} \\
(0.005)\end{array}$ & \\
\hline Id PC Dummy & & & & $\begin{array}{l}0.018^{* * *} \\
(0.004)\end{array}$ & \\
\hline After_BC_Law $\times$ Id PC Percentage & & & & & $\begin{array}{l}0.038^{* * *} \\
(0.006)\end{array}$ \\
\hline Id PC Percentage & & & & & $\begin{array}{l}0.073^{* * *} \\
(0.010)\end{array}$ \\
\hline After_BC_Law & $\begin{array}{l}-0.011 * * * \\
(0.003)\end{array}$ & $\begin{array}{l}-0.015 * * * \\
(0.003)\end{array}$ & $\begin{array}{l}-0.014^{* * *} \\
(0.002)\end{array}$ & $\begin{array}{l}-0.015^{* * *} \\
(0.003)\end{array}$ & $\begin{array}{l}-0.014 * * * \\
(0.002)\end{array}$ \\
\hline Size & $\begin{array}{l}0.045^{* * *} \\
(0.003)\end{array}$ & $\begin{array}{l}0.045^{* * *} \\
(0.003)\end{array}$ & $\begin{array}{l}0.046^{* * *} \\
(0.003)\end{array}$ & $\begin{array}{l}0.045^{* * *} \\
(0.003)\end{array}$ & $\begin{array}{l}0.046^{* * *} \\
(0.003)\end{array}$ \\
\hline Age & $\begin{array}{l}-0.025^{* * *} \\
(0.004)\end{array}$ & $\begin{array}{l}-0.025^{* * *} \\
(0.004)\end{array}$ & $\begin{array}{l}-0.025^{* * *} \\
(0.004)\end{array}$ & $\begin{array}{l}-0.026^{* * *} \\
(0.004)\end{array}$ & $\begin{array}{l}-0.025^{* * *} \\
(0.004)\end{array}$ \\
\hline Firm fixed effects & Yes & Yes & Yes & Yes & Yes \\
\hline State-year fixed effects & Yes & Yes & Yes & Yes & Yes \\
\hline Industry-year fixed effects & Yes & Yes & Yes & Yes & Yes \\
\hline Standard errors clustered (state of Incorporation) & Yes & Yes & Yes & Yes & Yes \\
\hline$R$-squared & 0.657 & 0.658 & 0.659 & 0.658 & 0.658 \\
\hline Number of observations & 96,064 & 96,064 & 96,064 & 96,064 & 96,064 \\
\hline
\end{tabular}


Table 4 Product Uniqueness and Effect of Business Combination Laws on Operating Performance of Dependent Suppliers

This table presents the estimates of OLS regressions of operating performance on the interactions among the status of dependent suppliers for principal customers, the product uniqueness measure, and the passage of Business Combination Laws in suppliers' states of incorporation. Our sample contains all Compustat firms in non-regulated industries for the period between 1979 and 1995. The dependent variable, ROA, is censored at 1st and 99th percentile values. Durable is a dummy variable that equals one if the firm belongs to the durable goods industries as defined in Gomes et al. (2009). High $R \& D$ is a dummy variable that equals one if the firm's research and development $(R \& D)$ ratio ( $R \& D$ expense/total assets) is higher than the median of all Compustat firms in the same year. Other control variables are defined as in Table 3. Industries are defined by the Fama and French 48 industry specification. We control for the firm fixed effects, the state-year fixed effects, and the industry-year fixed effects in all OLS regressions. The standard errors (in parentheses) are clustered at the state of incorporation level. ***, **, and $*$ denote statistical significance at the $1 \%, 5 \%$, and $10 \%$ level, respectively.

\begin{tabular}{|c|c|c|}
\hline & $(1)$ & (2) \\
\hline Variables & $R O A$ & $R O A$ \\
\hline After_BC_Law $\times$ PC Dummy $\times$ Durable & $\begin{array}{l}0.021 * * \\
(0.01)\end{array}$ & \\
\hline After_BC_Law $\times$ PC Dummy $\times$ High $R \& D$ & & $\begin{array}{l}0.015^{* *} \\
(0.006)\end{array}$ \\
\hline After_BC_Law $\times$ PC Dummy & $\begin{array}{l}0.010^{* *} \\
(0.005)\end{array}$ & $\begin{array}{l}0.007^{*} \\
(0.004)\end{array}$ \\
\hline After_BC_Law $\times$ Durable & $\begin{array}{l}-0.015^{* *} \\
(0.007)\end{array}$ & \\
\hline PC Dummy $\times$ Durable & $\begin{array}{l}-0.035^{* * *} \\
(0.009)\end{array}$ & \\
\hline After_BC_Law $\times$ High R\&D & & $\begin{array}{l}-0.010 \\
(0.007)\end{array}$ \\
\hline PC Dummy $\times$ High R\&D & & $\begin{array}{l}-0.003 \\
(0.006)\end{array}$ \\
\hline Durable & $\begin{array}{l}0.027 * * \\
(0.012)\end{array}$ & \\
\hline High $R \& D$ & & $\begin{array}{l}-0.043 * * * \\
(0.006)\end{array}$ \\
\hline PC Dummy & $\begin{array}{l}0.021 * * * \\
(0.003)\end{array}$ & $\begin{array}{l}0.019 * * * \\
(0.002)\end{array}$ \\
\hline After_BC_Law & $\begin{array}{l}-0.015^{* * * *} \\
(0.003)\end{array}$ & $\begin{array}{l}-0.013 * * * \\
(0.002)\end{array}$ \\
\hline Size & $\begin{array}{l}0.045^{* * *} \\
(0.003)\end{array}$ & $\begin{array}{l}0.045^{* * *} \\
(0.003)\end{array}$ \\
\hline Age & $\begin{array}{l}-0.025^{* * *} \\
(0.004)\end{array}$ & $\begin{array}{l}-0.025^{* * *} \\
(0.004)\end{array}$ \\
\hline Firm fixed effects & Yes & Yes \\
\hline State-year fixed effects & Yes & Yes \\
\hline Industry-year fixed effects & Yes & Yes \\
\hline Standard errors clustered (state of Incorporation) & Yes & Yes \\
\hline $\begin{array}{l}R \text {-squared } \\
\text { Number of observations }\end{array}$ & $\begin{array}{c}0.658 \\
96,064\end{array}$ & $\begin{array}{l}0.659 \\
96,064\end{array}$ \\
\hline
\end{tabular}




\section{Table 5 Effect of Business Combination Laws on Sales and Discretionary Expenses of Dependent Suppliers}

This table presents the estimates of OLS regressions of sales and discretionary expenses of dependent suppliers on the interaction between the status of dependent suppliers for principal customers and the passage of Business Combination Laws in suppliers' states of incorporation. Our sample contains all Compustat firms in non-regulated industries for the period between 1979 and 1995. Dependent variables are defined as follows for each year $t$ : Sales/Assets is total sales scaled by total assets. COGS/Sales is cost of goods sold scaled by total sales. SGA/Sales is selling, general, and administrative expenses scaled by total sales. The control variables are defined as in Table 3. Industries are defined by the Fama and French 48 industry specification. We control for the firm fixed effects, the state-year fixed effects, and the industry-year fixed effects in all OLS regressions. The standard errors (in parentheses) are clustered at the state of incorporation level. ***, $* *$, and $*$ denote statistical significance at the $1 \%, 5 \%$, and $10 \%$ level, respectively.

\begin{tabular}{|c|c|c|c|c|c|c|}
\hline & $(1)$ & (2) & (3) & (4) & $(5)$ & $(6)$ \\
\hline Variables & \multicolumn{2}{|c|}{ Sales/Assets } & \multicolumn{2}{|c|}{ COGS/Sales } & \multicolumn{2}{|c|}{ SGA/Sales } \\
\hline \multirow[t]{2}{*}{ After_BC_Law $\times$ PC Dummy } & 0.015 & & -0.013 & & $-0.016^{* *}$ & \\
\hline & $(0.019)$ & & $(0.009)$ & & $(0.007)$ & \\
\hline \multirow{2}{*}{ PC Dummy } & $0.025 * *$ & & $-0.016^{* * *}$ & & $-0.038 * * *$ & \\
\hline & $(0.010)$ & & $(0.004)$ & & $(0.008)$ & \\
\hline \multirow{2}{*}{ After_BC_Law $\times$ PC Percentage } & & 0.022 & & -0.014 & & $-0.043 *$ \\
\hline & & $(0.044)$ & & $(0.022)$ & & $(0.023)$ \\
\hline \multirow[t]{2}{*}{ PC Percentage } & & 0.016 & & $-0.050 * * *$ & & $-0.095 * * *$ \\
\hline & & $(0.032)$ & & $(0.014)$ & & $(0.031)$ \\
\hline \multirow[t]{2}{*}{ After_BC_Law } & $-0.026^{* *}$ & $-0.023 * *$ & $0.015 * *$ & $0.011^{*}$ & $0.023 * * *$ & $0.022 * * *$ \\
\hline & $(0.011)$ & $(0.010)$ & $(0.006)$ & $(0.006)$ & $(0.006)$ & $(0.007)$ \\
\hline \multirow[t]{2}{*}{ Size } & $-0.215^{* * *}$ & $-0.215^{* * *}$ & $-0.036 * * *$ & $-0.037 * * *$ & $-0.053 * * *$ & $-0.054 * * *$ \\
\hline & $(0.007)$ & $(0.007)$ & $(0.003)$ & $(0.003)$ & $(0.006)$ & $(0.006)$ \\
\hline \multirow[t]{2}{*}{ Age } & $0.093 * * *$ & $0.094 * * *$ & $0.015 * * *$ & $0.015^{* * *}$ & $-0.023 * *$ & $-0.023 * *$ \\
\hline & $(0.011)$ & $(0.011)$ & $(0.003)$ & $(0.003)$ & $(0.010)$ & $(0.010)$ \\
\hline Firm fixed effects & Yes & Yes & Yes & Yes & Yes & Yes \\
\hline State-year fixed effects & Yes & Yes & Yes & Yes & Yes & Yes \\
\hline Industry-year fixed effects & Yes & Yes & Yes & Yes & Yes & Yes \\
\hline Standard errors clustered (state of incorporation) & Yes & Yes & Yes & Yes & Yes & Yes \\
\hline$R$-squared & 0.847 & 0.847 & 0.645 & 0.646 & 0.723 & 0.723 \\
\hline Number of observations & 97,788 & 97,788 & 97,810 & 97,810 & 81,475 & 81,475 \\
\hline
\end{tabular}




\section{Table 6 Effect of Business Combination (BC) Laws on Sales to Principal Customers}

Column (1) presents the estimates of OLS regression of firms' number of principal customers on the passage of Business Combination Laws in suppliers' states of incorporation at the firm level. Columns (2) and (3) present the estimates of an OLS regression of percentage sales to principal customers on the passage of BC Laws in suppliers' states of incorporation at the firm level and the relationship level, respectively. Dependent variables are defined as follows: Num PC is the total number of all principal customers, and PC Percentage is the percentage sales of dependent suppliers to all principal customers in total sales. Independent variables are defined as in Table 3. Industries are defined by the Fama and French 48 industry specification. For specifications in columns (1) and (2), we control for the firm fixed effects, the state-year fixed effects, and the industry-year fixed effects. For specification in column (3), we control for the relationship fixed effects, the state-year fixed effects, and the industry-year fixed effects. The standard errors in all regressions (in parentheses) are clustered at the state of incorporation level. $* * *, * *$, and $*$ denote statistical significance at the $1 \%, 5 \%$, and $10 \%$ level, respectively.

\begin{tabular}{|c|c|c|c|}
\hline & (1) & (2) & (3) \\
\hline & Firm-Level & Firm-Level & Relationship-Level \\
\hline Variables & Num PC & PC Percentage & PC Percentage \\
\hline \multirow[t]{2}{*}{ After_BC_law } & $0.056^{* * *}$ & $0.009^{* * *}$ & $0.023 * *$ \\
\hline & $(0.013)$ & $(0.003)$ & $(0.011)$ \\
\hline \multirow[t]{2}{*}{ Size } & 0.001 & $-0.009 * * *$ & $-0.022 * *$ \\
\hline & $(0.008)$ & $(0.002)$ & $(0.009)$ \\
\hline \multirow[t]{2}{*}{ Age } & 0.018 & -0.002 & $-0.050 * * *$ \\
\hline & $(0.013)$ & $(0.003)$ & $(0.017)$ \\
\hline Firm fixed effects & Yes & Yes & - \\
\hline Relationship fixed effect & - & - & Yes \\
\hline State-year fixed effects & Yes & Yes & Yes \\
\hline Industry-year fixed effects & Yes & Yes & Yes \\
\hline Standard errors clustered (state of incorporation) & Yes & Yes & Yes \\
\hline$R$-squared & 0.677 & 0.726 & 0.764 \\
\hline Number of observations & 99,625 & 99,625 & 12,223 \\
\hline
\end{tabular}


Table 7 Cost of Changing Antitakeover Provisions and the Effect of Business Combination Laws on Operating Performance of Dependent Suppliers

This table presents the estimates of OLS regressions of operating performance on the interaction among the status of dependent suppliers for principal customers, the passage of Business Combination Laws in suppliers' states of incorporation, and a measure for the adjustment costs of firm-level antitakeover provisions. Our sample contains all Compustat firms in non-regulated industries for the period between 1979 and 1995 . The dependent variable, $R O A$, is censored at 1st and 99th percentile values. ATP Abs Change is the industry average of the annualized absolute change in the Governance Index (G-Index) due to firm-level provisions (i.e., excluding those determined by the state of incorporation) for the Fama and French 48 industry to which the firm belongs. This is calculated using Investor Responsibility Research Center (IRRC) data. Other control variables are defined as in Table 3. Industries are defined by the Fama and French 48 industry specification. We control for the firm fixed effects, the state-year fixed effects, and the industry-year fixed effects in all OLS regressions. The standard errors (in parentheses) are clustered at the state of incorporation level. ***,**, and * denote statistical significance at the $1 \%, 5 \%$, and $10 \%$ level, respectively.

\begin{tabular}{|c|c|c|}
\hline & $(1)$ & $(2)$ \\
\hline Variables & $R O A$ & $R O A$ \\
\hline After_BC_Law $\times$ PC Dummy $\times$ ATP Abs Change & $\begin{array}{l}-0.322^{* * *} \\
(0.113)\end{array}$ & \\
\hline After_BC_Law $\times$ PC Percentage $\times$ ATP Abs Change & & $\begin{array}{l}-1.083^{* * *} \\
(0.242)\end{array}$ \\
\hline After_BC_Law $\times$ ATP Abs Change & $\begin{array}{c}0.013 \\
(0.103)\end{array}$ & $\begin{array}{c}0.015 \\
(0.085)\end{array}$ \\
\hline After_BC_Law $\times$ PC Dummy & $\begin{array}{l}0.066^{* * *} \\
(0.018)\end{array}$ & \\
\hline After_BC_Law $\times$ PC Percentage & & $\begin{array}{l}0.214^{* * *} \\
(0.043)\end{array}$ \\
\hline PC Dummy $\times$ ATP Abs Change & $\begin{array}{c}0.128 \\
(0.141)\end{array}$ & \\
\hline PC Percentage $\times$ ATP Abs Change & & $\begin{array}{c}0.144 \\
(0.560)\end{array}$ \\
\hline PC Dummy & $\begin{array}{l}-0.003 \\
(0.025)\end{array}$ & \\
\hline PC Percentage & & $\begin{array}{c}0.037 \\
(0.101)\end{array}$ \\
\hline After_BC_Law & $\begin{array}{l}-0.017 \\
(0.017)\end{array}$ & $\begin{array}{l}-0.017 \\
(0.015)\end{array}$ \\
\hline Size & $\begin{array}{l}0.045^{* * * *} \\
(0.003)\end{array}$ & $\begin{array}{l}0.046^{* * *} \\
(0.003)\end{array}$ \\
\hline Age & $\begin{array}{l}-0.025^{* * *} \\
(0.004)\end{array}$ & $\begin{array}{l}-0.025 * * * \\
(0.004)\end{array}$ \\
\hline Firm fixed effects & Yes & Yes \\
\hline State-year fixed effects & Yes & Yes \\
\hline Industry-year fixed effects & Yes & Yes \\
\hline Standard errors clustered (state of incorporation) & Yes & Yes \\
\hline$R$-squared & 0.658 & 0.659 \\
\hline Number of observations & 96,064 & 96,064 \\
\hline
\end{tabular}




\section{Table 8 Effect of Business Combination (BC) Laws on Competing Suppliers}

For each law change year $t$, we identify principal customers with competing suppliers (i.e., within the same four-digit standard industrial classification (SIC) codes) incorporated in different states. We partition all dependent suppliers in this subsample into two groups: suppliers affected by the law change and competing suppliers. We require that at least one supplier is incorporated in the state with a BC Law change and at least one supplier is incorporated in the state that experiences no BC Law changes three years before and after year $t$. For suppliers in these two groups, we compute the average growth rate of sales to principal customers and average change of return on assets $(R O A)$ in the three years after the law change. The statistics for the suppliers incorporated in the states with law changes and for suppliers incorporated outside the states with law changes are reported in column (1) and column (2), respectively. In column (3), we report the average growth rate of sales to principal customers and the change in $R O A$ of all other suppliers in the same SIC four-digit industry. The differences between groups and their $t$-statistics are also reported in the table.

\begin{tabular}{|c|c|c|c|c|c|c|c|c|c|}
\hline \multirow{2}{*}{$\begin{array}{l}\text { Panel A } \\
\text { Year }\end{array}$} & \multicolumn{9}{|c|}{ Growth Rate of Sales to Principal Customers } \\
\hline & $\begin{array}{c}\text { (1) } \\
\text { Affected } \\
\text { suppliers }\end{array}$ & $\begin{array}{c}(2) \\
\text { Competing } \\
\text { suppliers }\end{array}$ & $\begin{array}{c}(3) \\
\text { Control } \\
\text { sample }\end{array}$ & $\begin{array}{l}\text { Difference } \\
\text { (1) - (3) }\end{array}$ & $\begin{array}{l}t \text {-statistic } \\
(1)-(3)\end{array}$ & $\begin{array}{l}\text { Difference } \\
(2)-(3)\end{array}$ & $\begin{array}{l}\text { t-statistic } \\
(2)-(3)\end{array}$ & $\begin{array}{l}\text { Difference } \\
(1)-(2)\end{array}$ & $\begin{array}{l}\text { t-statistic } \\
(1)-(2)\end{array}$ \\
\hline$Y 1$ & 0.309 & -0.014 & 0.057 & $0.251 * * *$ & 2.83 & $-0.071^{*}$ & -1.65 & $0.322 * * *$ & 3.38 \\
\hline$Y 2$ & 0.481 & -0.014 & 0.129 & $0.352 * *$ & 2.08 & $-0.143 * *$ & -2.38 & $0.495 * * *$ & 2.99 \\
\hline$Y 3$ & 0.479 & -0.031 & 0.157 & $0.322 * *$ & 2.36 & $-0.187 * *$ & -2.40 & $0.510^{* * *}$ & 3.69 \\
\hline Panel B & \multicolumn{9}{|c|}{ Change of ROA } \\
\hline Year & $(1)$ & $(2)$ & (3) & $(1)-(3)$ & T-stat (1) -(3) & $(2)-(3)$ & T-stat (2) -(3) & Difference & T-stat (1) -(2) \\
\hline$Y 1$ & 0.013 & -0.014 & -0.003 & $0.017 * *$ & 2.41 & $-0.010 * *$ & -1.98 & $0.027 * * *$ & 3.66 \\
\hline$Y 2$ & 0.016 & -0.024 & -0.002 & $0.018^{*}$ & 1.69 & $-0.022 * * *$ & -3.06 & $0.041 * * *$ & 3.75 \\
\hline$Y 3$ & 0.018 & -0.030 & -0.011 & $0.029 * *$ & 2.09 & $-0.019 * *$ & -2.24 & $0.048 * * *$ & 3.20 \\
\hline Number of observations & \multicolumn{9}{|c|}{156} \\
\hline
\end{tabular}




\section{Table 9 Effect of Business Combination Laws on the Continuation of Customer-Supplier Relationship}

This table presents the estimates of Cox proportional hazards model of the customer-supplier relationship discontinuation on the passage of Business Combination Laws in suppliers' states of incorporation and other timevarying control variables. The sample for tests in columns (1)-(4) contains all firms with identifiable principal customers (i.e., customers that can be identified by Compustat GVKEY) for the period 1979-1995. The failure in the model is defined by the event if the relationship with the principal customer discontinues in the next three years, $t+1, t+2, t+3$. We require that customer-supplier relationships included in our sample exist for more than one year. After_BC_Law is a dummy variable that equals one if Business Combination Laws have been passed in suppliers' state of incorporation and zero otherwise. Supplier Pct NonGov Customer is the percentage of sales to principal customers in a supplier's total sales. Pct COGS is the proportion of sales from the dependent supplier in customer's total cost of goods sold. Supplier Size (Customer Size) is the natural logarithm of supplier's (customer's) book value of total assets. Supplier ROA (Customer ROA) is the return on assets of the supplier (customer). The standard errors (in parentheses) are clustered at the suppliers' state of incorporation level. We also report hazards ratios for all coefficients. ${ }^{* *}, * *$, and $*$ denote statistical significance at the $1 \%, 5 \%$, and $10 \%$ level, respectively.

\begin{tabular}{|c|c|c|c|c|}
\hline \multirow[b]{2}{*}{ Variables } & \multicolumn{2}{|c|}{ (1) } & \multicolumn{2}{|c|}{$(2)$} \\
\hline & Hazards Ratio & Coef/SE & Hazards Ratio & Coef/SE \\
\hline \multirow[t]{2}{*}{ After_BC_Law } & 0.750 & $-0.287 * * *$ & 0.736 & $-0.306^{* * *}$ \\
\hline & & $(0.058)$ & & $(0.048)$ \\
\hline \multirow[t]{2}{*}{ Supplier Pct NonGov Customer } & 0.150 & $-1.894 * * *$ & 0.104 & $-2.262 * * *$ \\
\hline & & $(0.180)$ & & $(0.195)$ \\
\hline \multirow[t]{2}{*}{ Customer Pct COGS } & 0.876 & -0.132 & 0.889 & -0.117 \\
\hline & & $(0.088)$ & & $(0.072)$ \\
\hline \multirow[t]{2}{*}{ Supplier Size } & & & 0.891 & $-0.116 * * *$ \\
\hline & & & & $(0.013)$ \\
\hline \multirow[t]{2}{*}{ Supplier ROA } & & & 0.470 & $-0.755 * * *$ \\
\hline & & & & $(0.076)$ \\
\hline \multirow[t]{2}{*}{ Customer Size } & & & 0.961 & $-0.040 * * *$ \\
\hline & & & & $(0.012)$ \\
\hline \multirow[t]{2}{*}{ Customer ROA } & & & 0.742 & -0.299 \\
\hline & & & & $(0.224)$ \\
\hline $\begin{array}{l}\text { Standard errors clustered } \\
\text { (supplier's state of incorporation) }\end{array}$ & \multicolumn{2}{|c|}{ Yes } & \multicolumn{2}{|c|}{ Yes } \\
\hline Model $p$-value & \multicolumn{2}{|c|}{$<0.001$} & \multicolumn{2}{|c|}{$<0.001$} \\
\hline Number of observations & \multicolumn{4}{|c|}{12,223} \\
\hline
\end{tabular}




\section{Table 10 Effect of Business Combination Laws on the Sensitivity of Capital Investment and Operating}

Performance between Customers and Suppliers

This table presents the estimates of OLS regressions of the suppliers' capital investment (Capex) and operational performance $(R O A)$ on the interaction between their customers' capital investment and operational performance and the passage of Business Combination Laws in the supplier's state of incorporation. The sample for tests contains all pairs of dependent suppliers and their principal customers for the period 1979-1995. We require that all customersupplier relationships exist for more than one year. Supplier Capex/TA is the supplier's capital expenditure scaled by its total assets at year $t$. Supplier ROA is the return on assets of the supplier at year $t$. Similarly, Customer Capex/TA is the customer's capital expenditure scaled by its total assets at year $t$, and Customer ROA is the ROA of the customer at year $t$. In columns (1) and (3), the contemporaneous Capex/TA and ROA of customers are used. In columns (2) and (4), we use the lagged one-year Capex/TA and ROA of customers instead. Other independent variables are defined as in Table 3. We control for the year fixed effects and relationship fixed effects in all OLS regressions. The standard errors (in parentheses) are clustered at the customer-supplier relationship level. ***, **, and $*$ denote statistical significance at the $1 \%, 5 \%$, and $10 \%$ level, respectively.

To examine statistical significance using a different method, we randomly select peers of customer firms that belong to the same industry and the same size quintile. We carry out similar regressions as discussed above, replacing the customer firm with its randomly selected peer. This replacement test is repeated 1,000 times. The mean and standard deviation of 1,000 coefficients for the interaction terms in the regressions are reported in square brackets. The percentage of 1,000 coefficients that are larger than the coefficients for the true customer-supplier pairs is reported in pointed brackets. This can be interpreted as single-tail $p$-value. 
$\underline{\text { (Table } 10 \text { Continued) }}$

\begin{tabular}{|c|c|c|c|c|}
\hline \multirow[b]{2}{*}{ Variables } & (1) & (2) & (3) & (4) \\
\hline & $\begin{array}{c}\text { Supplier } \\
\text { Capex/TA }\end{array}$ & $\begin{array}{c}\text { Supplier } \\
\text { Capex/TA }\end{array}$ & $\begin{array}{c}\text { Supplier } \\
\text { ROA }\end{array}$ & $\begin{array}{c}\text { Supplier } \\
\text { ROA }\end{array}$ \\
\hline \multirow[t]{2}{*}{ Customer Capex $/$ TA $\times$ After_BC_law } & $0.095 * * *$ & & & \\
\hline & $(0.034)$ & & & \\
\hline \multirow[t]{2}{*}{ [Rand Capex $/ T A \times$ After_BC_law] } & {$[0.008,0.040]$} & & & \\
\hline & $<2.3 \%>$ & & & \\
\hline \multirow[t]{2}{*}{ Customer Capex/TA } & $0.060 * *$ & & & \\
\hline & $(0.022)$ & & & \\
\hline \multirow[t]{2}{*}{ Customer Capex $/ T A(-1) \times$ After_BC_law } & & $0.064 * *$ & & \\
\hline & & $(0.033)$ & & \\
\hline \multirow[t]{2}{*}{ [Rand Capex/TA(-1) $\times$ After_BC_law] } & & {$[-0.002,0.040]$} & & \\
\hline & & $<4.9 \%>$ & & \\
\hline \multirow[t]{2}{*}{ Customer Capex/TA (-1) } & & 0.014 & & \\
\hline & & $(0.021)$ & & \\
\hline \multirow[t]{2}{*}{ Customer ROA $\times$ After_BC_law } & & & $0.111^{* *}$ & \\
\hline & & & $(0.054)$ & \\
\hline \multirow[t]{2}{*}{ [Rand Customer ROA $\times$ After_BC_law] } & & & {$[-0.036,0.075]$} & \\
\hline & & & $<1.3 \%>$ & \\
\hline \multirow[t]{2}{*}{ Customer ROA } & & & $0.094 * * *$ & \\
\hline & & & $(0.034)$ & \\
\hline \multirow[t]{2}{*}{ Customer ROA(-1) $\times$ After_BC_law } & & & & $0.177 * * *$ \\
\hline & & & & $(0.053)$ \\
\hline \multirow[t]{2}{*}{ [Rand Customer ROA(-1) $\times$ After_BC_law] } & & & & {$[-0.013,0.072]$} \\
\hline & & & & $<0.3 \%>$ \\
\hline \multirow{2}{*}{ Customer ROA(-1) } & & & & 0.006 \\
\hline & & & & $(0.032)$ \\
\hline \multirow[t]{2}{*}{ After_BC_law } & -0.001 & -0.000 & $-0.029 * *$ & $-0.037 * * *$ \\
\hline & $(0.004)$ & $(0.004)$ & $(0.010)$ & $(0.010)$ \\
\hline \multirow[t]{2}{*}{ Supplier Age } & $-0.020 * * *$ & $-0.020 * * *$ & $-0.051 * * *$ & $-0.054 * * *$ \\
\hline & $(0.003)$ & $(0.003)$ & $(0.008)$ & $(0.008)$ \\
\hline \multirow[t]{2}{*}{ Supplier Size } & $0.009 * * *$ & $0.008 * * *$ & $0.053 * * *$ & $0.054 * * *$ \\
\hline & $(0.001)$ & $(0.002)$ & $(0.004)$ & $(0.004)$ \\
\hline Relationship fixed effects & Yes & Yes & Yes & Yes \\
\hline Year fixed effects & Yes & Yes & Yes & Yes \\
\hline Standard errors clustered (Relationship) & Yes & Yes & Yes & Yes \\
\hline$R$-squared & 0.576 & 0.578 & 0.644 & 0.645 \\
\hline Number of observations & 12,223 & 12,223 & 12,223 & 12,223 \\
\hline
\end{tabular}


Table 11 Effect of Successful and Unsuccessful Mergers and Acquisitions on the Continuation of CustomerSupplier Relationship

This table presents the estimates of probit regressions of the customer-supplier relationship continuation on the successful and unsuccessful attempts to acquire the suppliers by acquirers that are not the existing customers of these firms. The dependent variable, Cont $1 Y$ (Cont2Y), is a dummy variable that equals one if the relationship with the principal customer continues in the next (two) year(s) and zero if both the customer firm and the supplier firm still exist in Compustat but the relationship does not continue. Completed Deal is a dummy variable that equals one if the supplier is successfully acquired by at least one acquirer in year $t$ and zero otherwise. Withdrawn Deal is a dummy variable that equals one if there is at least one unsuccessful attempt to acquire the supplier in year $t$ and zero otherwise. Pct Cash is the percentage of deal value that would be paid in cash. In addition to coefficients and standard errors, we report the marginal effect of Completed Deal and Withdrawn Deal and their interactive terms with Pct Cash, evaluated at the means of all independent variables in square brackets. Other independent variables are defined as in Table 8. We control for the year fixed effects in all regressions. The standard errors (in parentheses) are clustered at the suppliers' states of incorporation level. $* * *, * *$, and $*$ denote statistical significance at the $1 \%, 5 \%$, and $10 \%$ level, respectively.

\begin{tabular}{|c|c|c|c|c|}
\hline \multirow[b]{2}{*}{ Variables } & \multicolumn{2}{|c|}{ Cont1Y } & \multicolumn{2}{|c|}{ Cont2Y } \\
\hline & (1) & (2) & (3) & (4) \\
\hline \multirow[t]{3}{*}{ Completed Deal } & $-0.598 * * *$ & -0.242 & $-0.520 * * *$ & -0.082 \\
\hline & $(0.125)$ & $(0.259)$ & $(0.110)$ & $(0.207)$ \\
\hline & {$[-0.178]$} & {$[-0.072]$} & {$[-0.201]$} & {$[-0.0302$} \\
\hline \multirow[t]{3}{*}{ Completed Deal $\times$ Pct Cash } & & $-0.872 * *$ & & $-1.199 * * *$ \\
\hline & & $(0.363)$ & & $(0.447)$ \\
\hline & & {$[-0.260]$} & & {$[-0.463]$} \\
\hline \multirow[t]{3}{*}{ Withdrawn Deal } & -0.230 & 0.011 & $-0.347 * *$ & -0.213 \\
\hline & $(0.216)$ & $(0.173)$ & $(0.151)$ & $(0.173)$ \\
\hline & {$[-0.069]$} & {$[0.003]$} & {$[-0.134]$} & {$[-0.082]$} \\
\hline \multirow[t]{3}{*}{ Withdrawn Deal $\times$ Pct Cash } & & $-0.522 * * *$ & & $-0.318^{*}$ \\
\hline & & $(0.195)$ & & $(0.192)$ \\
\hline & & {$[-0.155]$} & & {$[-0.123]$} \\
\hline \multirow[t]{2}{*}{ Past Relation Length } & $0.166 * * *$ & $0.167^{* * *}$ & $0.181 * * *$ & $0.182^{* * *}$ \\
\hline & $(0.023)$ & $(0.023)$ & $(0.023)$ & $(0.023)$ \\
\hline \multirow[t]{2}{*}{ NonGov Customer Sales Growth } & $0.076^{* * *}$ & $0.076^{* * *}$ & $0.048 * * *$ & $0.048^{* * *}$ \\
\hline & $(0.017)$ & $(0.017)$ & $(0.011)$ & $(0.011)$ \\
\hline \multirow[t]{2}{*}{ Supplier Pct NonGov Customer } & $1.592 * * *$ & $1.594 * * *$ & $1.535^{* * *}$ & $1.538^{* * *}$ \\
\hline & $(0.080)$ & $(0.081)$ & $(0.087)$ & $(0.085)$ \\
\hline \multirow{2}{*}{ Supplier ROA } & $0.770^{* * *}$ & $0.773 * * *$ & $0.940 * * *$ & $0.944 * * *$ \\
\hline & $(0.067)$ & $(0.068)$ & $(0.098)$ & $(0.099)$ \\
\hline \multirow[t]{2}{*}{ Supplier Size } & $0.087 * * *$ & $0.087 * * *$ & $0.098 * * *$ & $0.098 * * *$ \\
\hline & $(0.009)$ & $(0.009)$ & $(0.010)$ & $(0.010)$ \\
\hline \multirow[t]{2}{*}{ Customer Pct COGS } & -0.049 & -0.044 & 0.000 & 0.006 \\
\hline & $(0.162)$ & $(0.158)$ & $(0.275)$ & $(0.272)$ \\
\hline \multirow{2}{*}{ Customer ROA } & 0.196 & 0.205 & 0.307 & 0.317 \\
\hline & $(0.137)$ & $(0.135)$ & $(0.196)$ & $(0.197)$ \\
\hline \multirow[t]{2}{*}{ Customer Size } & $0.028 * * *$ & $0.028^{* * *}$ & $0.034 * * *$ & $0.034^{* * *}$ \\
\hline & $(0.008)$ & $(0.008)$ & $(0.011)$ & $(0.011)$ \\
\hline Year fixed effects & Yes & Yes & Yes & Yes \\
\hline Standard errors clustered (supplier's state of incorporation) & Yes & Yes & Yes & Yes \\
\hline Pseudo $R$-squared & 0.074 & 0.075 & 0.080 & 0.081 \\
\hline Number of observations & & & & 23 \\
\hline
\end{tabular}




\section{Table 12 Stock Returns after Business Combination (BC) Law Announcements}

This table presents the estimates of OLS regressions of post-BC Law announcement returns on the interaction between the status of dependent suppliers for principal customers and whether a firm is incorporated in the state where the BC Law change is announced. Following Giroud and Mueller (2010), we incorporate all 19 states where the announcement dates and passage dates of BC Laws can be identified. For each announcement, we include firms incorporated in the state where the announcement is made and states where there are no BC Law changes six months before and after the announcement date. The raw returns are adjusted by benchmark portfolio returns based on Fama and French 48 industry, size, and book-to-market ratio. Adj_Ret(Announced, Pass) is the adjusted cumulative return for the period from the date of announcement to the date of passage of BC Laws. Adj_Ret3M (Adj_Ret6M) is the adjusted cumulative return for a three-month (six-month) period after the announcement of BC Laws. Announcement State and PC Dummy are independent variables. Announcement State is a dummy variable that equals one if a firm is incorporated in the state where the announcement about the BC Law change is made and zero otherwise. PC Dummy is a dummy variable that equals one if this firm has at least one principal customer when the $\mathrm{BC}$ Law is announced and zero otherwise. We control for the announced state fixed effects. The standard errors (in parentheses) are clustered at the announced state level. $* * *, * *$ and $*$ denote statistical significance at the $1 \%, 5 \%$, and $10 \%$ level, respectively.

\begin{tabular}{lccc}
\hline & $(1)$ & $(2)$ & $(3)$ \\
Variables & Adj_Ret(Announced,Pass) & Adj_Ret3M & Adj_Ret6M \\
\hline Announced State & $-0.016^{* *}$ & $-0.013^{* * *}$ & $-0.022^{* * *}$ \\
& $(0.006)$ & $(0.003)$ & $(0.007)$ \\
PC Dummy & -0.004 & 0.001 & -0.001 \\
& $(0.004)$ & $(0.002)$ & $(0.002)$ \\
Announced State $\times$ PC Dummy & $0.039^{*}$ & $0.021^{* * *}$ & $0.024^{* *}$ \\
& $(0.020)$ & $(0.006)$ & $(0.010)$ \\
\hline Announced state fixed effect & Yes & Yes & Yes \\
Standard errors clustered (announced state) & Yes & Yes & Yes \\
Adj. $R$-squared & 0.001 & 0.001 & 0.001 \\
Number of observations & 62,041 & 62,041 & 62,041 \\
\hline
\end{tabular}




\section{Online Appendix}

\section{Section A: Examples of Customer-supplier Relationship Disruption due to Takeovers}

\section{A.1 Acquirer Debt and the Potential for Supply Disruption: Examples}

In Subsection 2.1, we argue that debt-financed acquisitions and debt-laden serial acquirers are often a source of supply disruption. In our sample period, debt financed takeovers, often characterized as hostile, were common. Moreover, an important feature of the BC laws is that they made it difficult for the acquirer to pay for the acquisitions by imposing restrictions on the use of the target assets - precisely the features that would make debt-financed acquisitions difficult. Here, we provide several examples of how acquirer debt led to disruptions.

The first example shows that a customer (McDonald's), concerned about supply disruption following a debt-financed acquisition of its supplier's parent company (Wilson), was instrumental in the sale of the subsidiary (Anderson) to a third party.

Example 1. Wilson and McDonald's

Wilson \& Co. began shipping fresh beef patties to McDonald's in 1968. In 1971, the Wilson meat plant incorporated as Anderson Meat and Provisions, and continued selling to McDonald's as a Wilson subsidiary. Sales to McDonald's Corporation accounted for 10.5 percent of Wilson's net sales in 1987. When Doskocil conducted a hostile takeover of Wilson in 1988, McDonald apparently refused to continue the purchase contract with the new owners. Wilson then agreed to sell Anderson to Oklahoma City veterinarian Norman Pick, Anderson's president. As a result, a company called Normac emerged. ${ }^{1}$

\footnotetext{
${ }^{1}$ In 1990, McDonald's approached Mr. Lopez, a longtime franchise owner in Los Angeles, about becoming part of the company's supply chain by buying Normac.
} 
Doskocil was already highly levered when it launched its bid for Wilson in 1988 (with a total liability to asset ratio in excess of 0.8). In 1987, Doskocil had repurchased nearly a million shares of its common stock. Late in that same year, the company raised \$57.5 million through the bond markets.

On February 28, 1990, Doskocil announced that the company and its subsidiaries, including the recently acquired Wilson Foods Corp., were in default on a \$133 million loan agreement. Chairman Larry Doskocil said the company's liquidity problems resulted, in part, from interest expense tied to Doskocil's \$238 million acquisition of Wilson Foods in 1988 and delays in selling Wilson's fresh and retail meats division.

The case illustrates the customer’s (McDonald's) refusal to invest in a relationship with a debtladen acquirer. While it could not prevent the takeover, it was an important enough customer that selling the Anderson division was the only way Doskocil could get any value for Anderson's relationship with McDonald.

Example 2: Debt-Financed Acquisitions in the Auto-Parts Industry in the 1990s

In the auto-parts supplier industry, a big wave of consolidations occurred in the 1990s, with the acquisitions mainly financed with debt. Eventually, the acquirers piled up too much debt and ran into financial trouble, which disrupted supplies to the automakers.

Notably, these events occurred in the age of "just-in-time” parts supply, when automakers started to maintain smaller inventories and their dependence on parts suppliers increased. The motive for the acquisition spree in the auto-parts supplier industry in the 1990s appears to have been to increase size to compete more effectively with larger firms within the industry.

An article published in Automotive News on May 13, $2002^{2}$ provides more perspective on the problems afflicting the parts suppliers. The article states that in the 1990s, General Motors and other automakers encouraged suppliers to expand rapidly. Vendors were expected to operate in all major world

\footnotetext{
2 “Too big to fail; GM props up ailing key suppliers to keep its assembly lines rolling”, by Robert Sherefkin, Automotive News, May 13, 2002, Vol. 76, Issue 5983.
} 
markets; they were also encouraged to design their own components, which made them key players in vehicle development. However, the desire to expand sparked an unprecedented wave of consolidation. In the 1990s, suppliers negotiated 272 mergers worth $\$ 19.5$ billion. As a result of that frenzy, many suppliers ended up with heavy burdens of debt. Faced with price pressures and declining production, in the short period between October 2001 and May 2002 half a dozen large suppliers, with combined sales of $\$ 7.4$ billion, sought Chapter 11 bankruptcy protection.

We discuss two specific cases below.

Example 2.1. Breed Technologies

Breed Technologies was a parts supplier to GM and other car manufacturers. Its example shows how dealing with a debt-laden acquirer (or one that finances its acquisitions by issuing debt) can be costly for the customer. In 1997, Breed acquired AlliedSignal's seat belt business, heavily financing the acquisition with debt. Soon after that, Breed ran into financial distress. In September, 1999, Breed Technologies nearly shut down nine GM truck plants after it stopped supplies of seat belts for 3 days. The reason for the disruption was a pricing dispute, resulting in a demand by Breed that GM pay \$44.5 million immediately to meet a repayment obligation. The shutdown would have been very costly to GM, with estimates showing a single day's stoppage resulting in a loss of $\$ 80$ million per day. Eventually, a court order restored the supply.

An article in Automotive News on September 6, 1999 states $^{3}$ : "The GM lawsuit also underscores the perils of merger mania among suppliers. Over the past five years, Breed spent \$1 billion to acquire 11 companies, part of its ambitious bid to compete against industry behemoths Autoliv Inc. and TRW Inc. Breed became the world's fourth-largest maker of airbags and seat belts. Now it is sinking under a mountain of debt."

Example 2.2. Oxford Automotive

\footnotetext{
3 “Breed, GM in belt battle: Price spat perils supply for truck", by Robert Sherefkin, Automotive News, September 9 , 1999, Vol. 74, Issue 5836.
} 
In the course of customer-supplier relationships, the customer may need to exploit its bargaining power to ensure quality. However, imposing penalties in the form of withholding payments can be difficult if the supplier has too much debt. Thus, customers will be opposed to acquisitions of their conservatively financed suppliers by firms that are highly levered or that finance the acquisition with debt. Regulation such as the BC laws that make debt-financed acquisitions difficult is thus good for customer-supplier relationships.

An example is Oxford, a supplier of suspensions and chassis components. With worldwide sales of \$824 million, the Troy, Mich., business was a key supplier for GM's profitable compact sport-utility vehicles. In 2001, the company spent heavily on factories and tooling to supply components for nine new vehicles. Unable to comply with the terms of its bank loans, Oxford began Chapter 11 reorganization proceedings in January of 2002. What complicated matters for GM was an ongoing dispute with Oxford regarding supplies of defective parts. The two companies were locked in a dispute over a defective part that forced the recall of 6,000 Chevrolet TrailBlazers, GMC Envoys and Oldsmobile Bravadas. Oxford's financial woes made it difficult for GM to withhold millions of dollars in payments to Oxford for the defective parts.

\section{A.2 Acquirer Opportunism and Supply Disruption: Flextronics’ Acquisition of Dovatron}

In Subsection 2.3, we argue that the acquirer might be interested in the supplier's assets if it has plans for deploying these assets for alternative uses, including meeting supply targets for its own customers. Flextronics' acquisition of Dovatron is an example of an acquirer's being more interested in the supplier's other business than that with the customer, Beckman Coulter. Beckman Coulter was Dovatron's customer for switchboards needed for the manufacture of medical instruments. In April of 2000, Flextronics purchased Dovatron. On May 30, 2000, however, Flextronics notified all the customers of Dovatron's Anaheim facility, including Beckman Coulter, that it was closing its doors within 90 days, and that employees were being terminated. The following day Flextronics announced in a public press release that it had just entered into a \$30 billion contract with Motorola. It was revealed during testimony at the trial that Flextronics was switching from "high mix low volume" business to "low mix high volume" business. 
In other words, it no longer wanted to manufacture complicated circuit boards for Beckman Coulter's LX20 but rather was choosing to make simpler circuit boards, such as for cell phones for Motorola. 


\section{Section B: Additional Empirical Results}

\section{Table B1 Effect of Business Combination Laws on Operating Performance of Dependent Suppliers—Additional Control Variables}

This table presents the estimates of OLS regressions of operating performance on the interaction between the status of dependent suppliers for principal customers and the passage of Business Combination Laws in suppliers' states of incorporation. Columns (1)-(4) present the regressions results of columns (2)(5) of Table 3 with various control variables. Leverage is the sum of debts in current liability and long-term liability scaled by the book value of total assets; Cash is the cash and equivalent scaled by the book value of total assets; Tangibility is the property, plant, and equipment scaled by the book value of total assets; and Standard Deviation of Returns is the standard deviation of daily returns within the fiscal year. Leverage, Cash, Tangibility, and Standard Deviation of Returns are winsorized at the $1 \%$ and $99 \%$ levels. We control for the firm fixed effects, the state-year fixed effects, and the industry-year fixed effects in all OLS regressions. Industries are defined by the Fama and French 48 industry specification. The standard errors (in parentheses) are clustered at the state of incorporation level. $* * *, * *$, and $*$ denote statistical significance at the $1 \%, 5 \%$, and $10 \%$ level, respectively. 


\section{(Table B1 Continued)}

\begin{tabular}{|c|c|c|c|c|c|c|}
\hline Variables & $\begin{array}{c}(1) \\
R O A \\
\end{array}$ & $\begin{array}{c}(2) \\
R O A \\
\end{array}$ & $\begin{array}{c}(3) \\
R O A \\
\end{array}$ & $\begin{array}{c}(4) \\
R O A \\
\end{array}$ & $\begin{array}{c}(5) \\
R O A \\
\end{array}$ & $\begin{array}{c}(6) \\
R O A \\
\end{array}$ \\
\hline \multirow[t]{2}{*}{ After_BC_Law $\times$ PC Dummy } & $0.009 * *$ & $0.011 * *$ & $0.012 * * *$ & & & \\
\hline & $(0.004)$ & $(0.004)$ & $(0.004)$ & & & \\
\hline \multirow[t]{2}{*}{ PC Dummy } & $0.020^{* * *}$ & $0.018^{* * *}$ & $0.012^{* * *}$ & & & \\
\hline & $(0.003)$ & $(0.003)$ & $(0.003)$ & & & \\
\hline \multirow[t]{2}{*}{ After_BC_Law $\times$ PC Percentage } & & & & $0.023 * * *$ & $0.028 * * *$ & $0.026 * * *$ \\
\hline & & & & $(0.006)$ & $(0.006)$ & $(0.008)$ \\
\hline \multirow[t]{2}{*}{ PC Percentage } & & & & $0.065^{* * *}$ & $0.058^{* * *}$ & $0.049 * * *$ \\
\hline & & & & $(0.007)$ & $(0.008)$ & $(0.009)$ \\
\hline \multirow{2}{*}{ After_BC_Law } & $-0.013^{* * *}$ & $-0.014 * * *$ & $-0.010^{* *}$ & $-0.012 * * *$ & $-0.013 * * *$ & $-0.009 * *$ \\
\hline & $(0.003)$ & $(0.004)$ & $(0.004)$ & $(0.002)$ & $(0.003)$ & $(0.004)$ \\
\hline \multirow[t]{2}{*}{ Size } & $0.042 * * *$ & $0.043^{* * *}$ & $0.043 * * *$ & $0.043 * * *$ & $0.043 * * *$ & $0.044 * * *$ \\
\hline & $(0.003)$ & $(0.003)$ & $(0.003)$ & $(0.003)$ & $(0.003)$ & $(0.003)$ \\
\hline \multirow[t]{2}{*}{ Age } & & $-0.027 * * *$ & 0.007 & & $-0.026 * * *$ & 0.007 \\
\hline & & $(0.004)$ & $(0.006)$ & & $(0.004)$ & $(0.006)$ \\
\hline \multirow[t]{2}{*}{ Leverage } & & $-0.129 * * *$ & $-0.158 * * *$ & & $-0.128 * * *$ & $-0.158 * * *$ \\
\hline & & $(0.004)$ & $(0.006)$ & & $(0.004)$ & $(0.006)$ \\
\hline \multirow[t]{2}{*}{ Cash } & & $-0.039 * * *$ & $-0.018 *$ & & $-0.041 * * *$ & $-0.018 *$ \\
\hline & & $(0.014)$ & $(0.009)$ & & $(0.014)$ & $(0.009)$ \\
\hline \multirow[t]{2}{*}{ Tangibility } & & $-0.032 * * *$ & $-0.038 * * *$ & & $-0.032 * * *$ & $-0.038 * * *$ \\
\hline & & $(0.009)$ & $(0.007)$ & & $(0.009)$ & $(0.007)$ \\
\hline \multirow[t]{2}{*}{ After_BC_Law $\times$ HHI } & & -0.003 & 0.007 & & -0.003 & 0.007 \\
\hline & & $(0.010)$ & $(0.009)$ & & $(0.010)$ & $(0.009)$ \\
\hline \multirow[t]{2}{*}{ Standard Deviation of Returns } & & & $-0.732 * * *$ & & & $-0.729 * * *$ \\
\hline & & & $(0.055)$ & & & $(0.054)$ \\
\hline Firm fixed effects & Yes & Yes & Yes & Yes & Yes & Yes \\
\hline State-year fixed effects & Yes & Yes & Yes & Yes & Yes & Yes \\
\hline Industry-year fixed effects & Yes & Yes & Yes & Yes & Yes & Yes \\
\hline Standard errors clustered (state of incorporation) & Yes & Yes & Yes & Yes & Yes & Yes \\
\hline$R$-squared & 0.657 & 0.668 & 0.711 & 0.658 & 0.669 & 0.711 \\
\hline Number of observations & 96,064 & 89,578 & 56,387 & 96,064 & 89,578 & 56,387 \\
\hline
\end{tabular}




\section{Table B2 Effect of Business Combination Laws on Number of Principal Customers - Poisson Regression}

Column (1) of this table presents the estimates from a Poisson regression of firms' numbers of principal customers on the passage of Business Combination Law in suppliers' states of incorporation at the firm level. The dependent variable, Num PC, is defined as the total number of principal customers that account for more than $10 \%$ of sales of the supplier firm. Independent variables are defined in the same way as described in Table 3 . We control for the firm fixed effects and year fixed effects. The standard errors in all regressions (in parentheses) are clustered at the firm level. ${ }^{* * *},{ }^{* *}$, and $*$ denote statistical significance at the $1 \%, 5 \%$, and $10 \%$ level, respectively.

\begin{tabular}{lc}
\hline & $(1)$ \\
\hline After_BC_law & Num PC \\
& $0.108^{* * *}$ \\
Size & $(0.028)$ \\
& $0.027^{* *}$ \\
Age & $(0.012)$ \\
& $-0.083^{* * *}$ \\
Firm Fixed Effects & $(0.023)$ \\
Year Fixed Effects & Yes \\
Standard errors clustered (Firm) & Yes \\
\hline Number of observations & Yes \\
\hline
\end{tabular}




\section{Table B3 Effect of Business Combination (BC) Laws on Asset Growth of Suppliers-Firm-Years around BC Law Passage}

This table presents the estimates of OLS regressions of logarithm of asset growth (log of the following ratio: total assets/total assets at the end of the previous year) on the interaction between the status of dependent suppliers for principal customers and the passage of Business Combination Laws in suppliers' states of incorporation. Columns (1)-(4) present the regressions results similar to Columns (2)-(3) of Table 3 with one change: Only firm-years that are within a four-year window of passage of a BC Law for firms incorporated in that state are kept in the sample. We control for the firm fixed effects, the state-year fixed effects, and the industry-year fixed effects in all OLS regressions. Industries are defined by the Fama and French 48 industry specification. The standard errors (in parentheses) are clustered at the state of incorporation level. ***, **, and * denotes statistical significance at the $1 \%, 5 \%$, and $10 \%$ level, respectively.

\begin{tabular}{|c|c|c|c|c|}
\hline Variables & $\begin{array}{c}\text { (1) } \\
\text { Asset Growth }\end{array}$ & $\begin{array}{c}\text { (2) } \\
\text { Asset Growth }\end{array}$ & $\begin{array}{c}\text { (3) } \\
\text { Asset Growth }\end{array}$ & $\begin{array}{c}\text { (4) } \\
\text { Asset Growth }\end{array}$ \\
\hline After_BC_Law $\times$ PC Dummy & $\begin{array}{c}0.036 * * * \\
(0.012)\end{array}$ & & $\begin{array}{c}0.041 * * * \\
(0.013)\end{array}$ & \\
\hline PC Dummy & $\begin{array}{c}0.002 \\
(0.009)\end{array}$ & & $\begin{array}{l}-0.004 \\
(0.010)\end{array}$ & \\
\hline After_BC_Law $\times$ PC Percentage & & $\begin{array}{c}0.109 * * * \\
(0.027)\end{array}$ & & $\begin{array}{c}0.135^{* * *} \\
(0.027)\end{array}$ \\
\hline PC Percentage & & $\begin{array}{l}-0.012 \\
(0.031)\end{array}$ & & $\begin{array}{c}0.019 \\
(0.029)\end{array}$ \\
\hline After_BC_Law & $\begin{array}{l}-0.005 \\
(0.009)\end{array}$ & $\begin{array}{l}-0.003 \\
(0.007)\end{array}$ & $\begin{array}{l}-0.012 \\
(0.009)\end{array}$ & $\begin{array}{l}-0.011 \\
(0.007)\end{array}$ \\
\hline Size & & & $\begin{array}{c}0.234^{* * * *} \\
(0.003)\end{array}$ & $\begin{array}{c}0.236 * * * \\
(0.003)\end{array}$ \\
\hline Age & $\begin{array}{c}-0.314^{* * *} \\
(0.018)\end{array}$ & $\begin{array}{c}-0.316^{* * *} \\
(0.017)\end{array}$ & $\begin{array}{c}-0.370^{* * *} \\
(0.017)\end{array}$ & $\begin{array}{c}-0.373^{* * *} \\
(0.017)\end{array}$ \\
\hline Firm fixed effects & Yes & Yes & Yes & Yes \\
\hline State-year fixed effects & Yes & Yes & Yes & Yes \\
\hline Industry-year fixed effects & Yes & Yes & Yes & Yes \\
\hline Standard errors clustered (state of incorporation) & Yes & Yes & Yes & Yes \\
\hline $\begin{array}{l}R \text {-squared } \\
\text { Number of observations }\end{array}$ & $\begin{array}{c}0.336 \\
32,883\end{array}$ & $\begin{array}{c}0.336 \\
32,883\end{array}$ & $\begin{array}{c}0.418 \\
32,883\end{array}$ & $\begin{array}{c}0.419 \\
32,883\end{array}$ \\
\hline
\end{tabular}




\section{Table B4 The Impact of Business Combination Laws on the Takeover Likelihood}

This table presents the estimates of the logit models for the Compustat firms for the sample period 1981-1995. We only include successful or withdrawn mergers and acquisitions that attempt to change corporate controls for the target firms, i.e., the ownership of acquirers is lower than $50 \%$ before the deal but the mergers and acquisitions would make their holdings higher than $50 \%$ after the deals. Hostile is a dummy variable that equals one if a firm is targeted by at least one hostile acquirer, as classified by the SDC database, in year $t$, and zero otherwise. Friendly is a dummy variable that equals one if a firm is targeted in year $t$ by acquirers that are not classified as hostile by the SDC database, and zero otherwise. All is a dummy variable that equals one if a firm is targeted in year $t$, and zero otherwise. After_BC_Law is a dummy variable that equals one if the Business Combination Law has passed in suppliers' state of incorporation (i.e., based on the state of incorporation when the supplier first enters our sample), and zero otherwise. Other independent variables are defined following Cremers, Nair and John (2008). Tobin-Q is the ratio of market-to-book value of assets. PPE is the ratio of property, plant, and equipment to total assets. $L n$ (Cash) is the natural logarithm of the ratio of cash and short-term investments scaled by total assets. BLOCK is a dummy variable that equals one if at least one institutional investor holding more than $5 \%$ of the company and zero otherwise. $L n$ (Mktcap) is the natural logarithm of market value of equity. Industry is a dummy variable that equals 1 if there was at least one takeover in this firm industry in the previous year. Leverage is the ratio of book debt to total assets. ROA is the return on assets. Pass_law is a dummy variable that equals one if the state of incorporation of the firm passed Business Combination Laws at some point during our sample period, and zero otherwise. Except for After_BC_Law and Pass_law, all independent variables are lagged by one year. The logit regressions include year dummies which are not reported and the standard errors, reported in the parentheses, are clustered at the firm level. . $* * *$, ** and $*$ denotes statistical significance at the $1 \%, 5 \%$, and $10 \%$ level, respectively. The marginal effects of After_BC_Law at the mean values of other independent variables are reported in the pointed brackets. 


\begin{tabular}{|c|c|c|c|}
\hline & All & Hostile & Friendly \\
\hline Variables & (1) & (2) & (3) \\
\hline \multirow[t]{3}{*}{ After_BC_Law } & $-0.344 * * *$ & $0.500 * *$ & $-0.280 * *$ \\
\hline & (0.111) & $(0.226)$ & $(0.124)$ \\
\hline & $<-0.0047>$ & $<-0.0012>$ & $<-0.0030>$ \\
\hline \multirow[t]{2}{*}{ Tobin's $Q$} & $-0.235^{* * *}$ & $-0.671^{* * *}$ & $-0.158 * * *$ \\
\hline & $(0.045)$ & $(0.172)$ & $(0.044)$ \\
\hline \multirow[t]{2}{*}{$P P E$} & 0.009 & $0.271^{*}$ & -0.089 \\
\hline & $(0.080)$ & $(0.146)$ & $(0.091)$ \\
\hline \multirow[t]{2}{*}{$\operatorname{Ln}($ Cash $)$} & 0.010 & 0.003 & 0.016 \\
\hline & $(0.025)$ & $(0.051)$ & $(0.028)$ \\
\hline \multirow[t]{2}{*}{ BLOCK } & $0.677 * * *$ & $0.572 * * *$ & $0.726 * * *$ \\
\hline & $(0.081)$ & $(0.161)$ & $(0.090)$ \\
\hline \multirow[t]{2}{*}{ Ln(Mktcap) } & $-0.089 * * *$ & $0.118^{* * *}$ & $-0.157^{* * *}$ \\
\hline & $(0.021)$ & $(0.040)$ & $(0.023)$ \\
\hline \multirow[t]{2}{*}{ Industry } & 0.096 & $0.324^{* *}$ & 0.063 \\
\hline & $(0.103)$ & $(0.161)$ & $(0.101)$ \\
\hline \multirow[t]{2}{*}{ Leverage } & $0.555^{* * *}$ & -0.220 & $0.734 * * *$ \\
\hline & $(0.177)$ & $(0.371)$ & (0.196) \\
\hline \multirow[t]{2}{*}{$R O A$} & $-0.390 *$ & 0.016 & -0.335 \\
\hline & $(0.209)$ & $(0.512)$ & $(0.227)$ \\
\hline \multirow[t]{2}{*}{ Pass_Law } & 0.106 & $0.357^{*}$ & 0.035 \\
\hline & $(0.096)$ & $(0.211)$ & $(0.106)$ \\
\hline Psudo $\mathrm{R}^{2}$ & 0.041 & 0.067 & 0.039 \\
\hline Number of Observations (firm-year) & 57118 & 57118 & 57118 \\
\hline Number of Targets & 976 & 208 & 768 \\
\hline Standard errors clustered (Firm) & Yes & Yes & Yes \\
\hline
\end{tabular}


Table B5 Effect of Business Combination (BC) Laws on Return on Assets (ROA) of Suppliers - Post-1983 sample

This table presents the estimates of OLS regressions of operating performance on the interaction between the status of dependent suppliers for principal customers and the passage of Business Combination Laws in suppliers' states of incorporation. Columns (1)-(4) present the regressions results of columns (2)-(5) of Table 3 with one change: the sample period is from 1984 to $1995 . * * *$, **, and * denote statistical significance at the $1 \%, 5 \%$, and $10 \%$ level, respectively.

\begin{tabular}{|c|c|c|c|c|}
\hline Variables & $\begin{array}{c}(1) \\
R O A\end{array}$ & $\begin{array}{c}(2) \\
R O A\end{array}$ & $\begin{array}{c}(3) \\
R O A\end{array}$ & $\begin{array}{c}(4) \\
R O A\end{array}$ \\
\hline After_BC_Law $\times$ PC Dummy & $\begin{array}{l}0.018^{* * * *} \\
(0.004)\end{array}$ & & & \\
\hline PC Dummy & $\begin{array}{l}0.016^{* * *} \\
(0.003)\end{array}$ & & & \\
\hline After_BC_Law $\times$ PC Percentage & & $\begin{array}{l}0.043^{* * *} \\
(0.009)\end{array}$ & & \\
\hline PC Percentage & & $\begin{array}{l}0.073^{* * * *} \\
(0.014)\end{array}$ & & \\
\hline After_BC_Law $\times$ Id PC Dummy & & & $\begin{array}{l}0.020^{* * *} \\
(0.005)\end{array}$ & \\
\hline Id PC Dummy & & & $\begin{array}{l}0.014^{* * *} \\
(0.004)\end{array}$ & \\
\hline After_BC_Law $\times$ Id PC Percentage & & & & $\begin{array}{l}0.054^{* * *} \\
(0.011)\end{array}$ \\
\hline Id PC Percentage & & & & $\begin{array}{l}0.084^{* * *} \\
(0.017)\end{array}$ \\
\hline After_BC_Law & $\begin{array}{l}-0.015^{* * *} \\
(0.003)\end{array}$ & $\begin{array}{l}-0.012^{* * *} \\
(0.003)\end{array}$ & $\begin{array}{l}-0.013^{* * *} \\
(0.003)\end{array}$ & $\begin{array}{l}-0.011^{* * *} \\
(0.003)\end{array}$ \\
\hline Size & $\begin{array}{l}0.047^{* * *} \\
(0.002)\end{array}$ & $\begin{array}{l}0.049 * * * \\
(0.002)\end{array}$ & $\begin{array}{l}0.048^{* * *} \\
(0.002)\end{array}$ & $\begin{array}{l}0.048^{* * *} \\
(0.002)\end{array}$ \\
\hline Age & $\begin{array}{l}-0.022^{* * *} \\
(0.004)\end{array}$ & $\begin{array}{l}-0.022^{* * *} \\
(0.004)\end{array}$ & $\begin{array}{l}-0.022 * * * \\
(0.004)\end{array}$ & $\begin{array}{l}-0.022 * * * \\
(0.004)\end{array}$ \\
\hline Firm fixed effects & Yes & Yes & Yes & Yes \\
\hline State-year fixed effects & Yes & Yes & Yes & Yes \\
\hline Industry-year fixed effects & Yes & Yes & Yes & Yes \\
\hline Standard errors clustered (state of incorporation) & Yes & Yes & Yes & Yes \\
\hline$R$-squared & 0.682 & 0.683 & 0.682 & 0.683 \\
\hline Number of observations & 76,767 & 76,767 & 76,767 & 76,767 \\
\hline
\end{tabular}


Table B6 Effect of Business Combination (BC) Laws on Return on Assets (ROA) of Suppliers - Only Delaware firms in the treatment group

This table presents the estimates of OLS regressions of operating performance on the interaction between the status of dependent suppliers for principal customers and the passage of Business Combination Laws in suppliers' states of incorporation. Columns (1)-(4) present the regressions results of columns (2)-(5) of Table 3 with one change: the After BC Law Delaware dummy is turned on only for firms incorporated in Delaware, after Delaware passed BC Laws. For all other firms it remains zero. ***, **, and * denote statistical significance at the $1 \%, 5 \%$, and $10 \%$ level, respectively.

\begin{tabular}{|c|c|c|c|c|}
\hline Variables & $\begin{array}{c}(1) \\
R O A\end{array}$ & $\begin{array}{c}(2) \\
R O A\end{array}$ & $\begin{array}{c}(3) \\
R O A\end{array}$ & $\begin{array}{c}(4) \\
R O A\end{array}$ \\
\hline After_BC_Law Delaware $\times$ PC Dummy & $\begin{array}{l}0.014^{* * *} \\
(0.003)\end{array}$ & & & \\
\hline PC Dummy & $\begin{array}{l}0.020^{* * *} \\
(0.003)\end{array}$ & & & \\
\hline After_BC_Law_Delaware $\times$ PC Percentage & & $\begin{array}{l}0.027 * * * \\
(0.007)\end{array}$ & & \\
\hline PC Percentage & & $\begin{array}{l}0.067 * * * \\
(0.009)\end{array}$ & & \\
\hline After_BC_Law_Delaware $\times$ Id PC Dummy & & & $\begin{array}{l}0.015^{* * *} \\
(0.003)\end{array}$ & \\
\hline Id PC Dummy & & & $\begin{array}{l}0.020^{* * *} \\
(0.004)\end{array}$ & \\
\hline After_BC_Law_Delaware $\times$ Id PC Percentage & & & & $\begin{array}{l}0.020^{* *} \\
(0.009)\end{array}$ \\
\hline Id PC Percentage & & & & $\begin{array}{l}0.083^{* * *} \\
(0.012)\end{array}$ \\
\hline After_BC_Law_Delaware & $\begin{array}{l}-0.011^{* * *} \\
(0.002)\end{array}$ & $\begin{array}{l}-0.009 * * * \\
(0.002)\end{array}$ & $\begin{array}{l}-0.010^{* * *} \\
(0.002)\end{array}$ & $\begin{array}{l}-0.007 * * * \\
(0.002)\end{array}$ \\
\hline Size & $\begin{array}{l}0.045^{* * *} \\
(0.003)\end{array}$ & $\begin{array}{l}0.046^{* * *} \\
(0.003)\end{array}$ & $\begin{array}{l}0.045^{* * *} \\
(0.003)\end{array}$ & $\begin{array}{l}0.046^{* * *} \\
(0.003)\end{array}$ \\
\hline Age & $\begin{array}{l}-0.025^{* * *} \\
(0.004)\end{array}$ & $\begin{array}{l}-0.025^{* * *} \\
(0.004)\end{array}$ & $\begin{array}{l}-0.025^{* * *} \\
(0.004)\end{array}$ & $\begin{array}{l}-0.025^{* * *} \\
(0.004)\end{array}$ \\
\hline Firm fixed effects & Yes & Yes & Yes & Yes \\
\hline State-year fixed effects & Yes & Yes & Yes & Yes \\
\hline Industry-year fixed effects & Yes & Yes & Yes & Yes \\
\hline Standard errors clustered (state of incorporation) & Yes & Yes & Yes & Yes \\
\hline $\begin{array}{l}R \text {-squared } \\
\text { Number of observations }\end{array}$ & $\begin{array}{c}0.658 \\
96,064\end{array}$ & $\begin{array}{c}0.659 \\
96,064\end{array}$ & $\begin{array}{c}0.658 \\
96,064\end{array}$ & $\begin{array}{c}0.658 \\
96,064\end{array}$ \\
\hline
\end{tabular}


Table B7 Effect of Business Combination Laws on Operating Performance of Dependent Suppliers, Clustered at Firm Level

This table presents the estimates of OLS regressions of operating performance on the interaction between the status of dependent suppliers for principal customers and the passage of Business Combination Laws in suppliers' states of incorporation. Columns (1)-(4) present the regressions results of columns (2)-(5) of Table 3 with one change: The standard errors are clustered at the firm level. ${ }^{* * *}, * *$, and $*$ denote statistical significance at the $1 \%, 5 \%$, and $10 \%$ level,

\begin{tabular}{|c|c|c|c|c|}
\hline Variables & $\begin{array}{c}(1) \\
R O A\end{array}$ & $\begin{array}{c}(2) \\
R O A\end{array}$ & $\begin{array}{c}(3) \\
R O A\end{array}$ & $\begin{array}{c}(4) \\
R O A\end{array}$ \\
\hline After_BC_Law $\times$ PC Dummy & $\begin{array}{l}0.011^{* * *} \\
(0.004)\end{array}$ & & & \\
\hline PC Dummy & $\begin{array}{l}0.019 * * * \\
(0.003)\end{array}$ & & & \\
\hline After_BC_Law $\times$ PC Percentage & & $\begin{array}{l}0.030^{* * *} \\
(0.011)\end{array}$ & & \\
\hline PC Percentage & & $\begin{array}{l}0.062^{* * *} \\
(0.009)\end{array}$ & & \\
\hline After_BC_Law $\times$ Id PC Dummy & & & $\begin{array}{l}0.012^{* * *} \\
(0.004)\end{array}$ & \\
\hline Id PC Dummy & & & $\begin{array}{l}0.018^{* * *} \\
(0.003)\end{array}$ & \\
\hline After_BC_Law $\times$ Id PC Percentage & & & & $\begin{array}{l}0.038^{* * * *} \\
(0.014)\end{array}$ \\
\hline Id PC Percentage & & & & $\begin{array}{l}0.073^{* * * *} \\
(0.011)\end{array}$ \\
\hline After_BC_Law & $\begin{array}{l}-0.015^{* * *} \\
(0.004)\end{array}$ & $\begin{array}{l}-0.014 * * * \\
(0.004)\end{array}$ & $\begin{array}{l}-0.015^{* * *} \\
(0.003)\end{array}$ & $\begin{array}{l}-0.014 * * * \\
(0.004)\end{array}$ \\
\hline Size & $\begin{array}{l}0.045^{* * *} \\
(0.002)\end{array}$ & $\begin{array}{l}0.046^{* * * *} \\
(0.002)\end{array}$ & $\begin{array}{l}0.045^{* * *} \\
(0.002)\end{array}$ & $\begin{array}{l}0.046^{* * *} \\
(0.002)\end{array}$ \\
\hline Age & $\begin{array}{l}-0.025 * * * \\
(0.003)\end{array}$ & $\begin{array}{l}-0.025^{* * * *} \\
(0.003)\end{array}$ & $\begin{array}{l}-0.026^{* * *} \\
(0.003)\end{array}$ & $\begin{array}{l}-0.025^{* * *} \\
(0.003)\end{array}$ \\
\hline Firm fixed effects & Yes & Yes & Yes & Yes \\
\hline State-year fixed effects & Yes & Yes & Yes & Yes \\
\hline Industry-year fixed effects & Yes & Yes & Yes & Yes \\
\hline Standard errors clustered (firm) & Yes & Yes & Yes & Yes \\
\hline $\begin{array}{l}R \text {-squared } \\
\text { Number of observations }\end{array}$ & $\begin{array}{c}0.658 \\
96.064\end{array}$ & $\begin{array}{c}0.659 \\
96.064\end{array}$ & $\begin{array}{c}0.658 \\
96.064\end{array}$ & $\begin{array}{l}0.658 \\
96064\end{array}$ \\
\hline
\end{tabular}




\section{Section C: A Numerical Example}

Here, we provide a numerical example to show that when a supplier firm receives a new project from the principal customer (e.g., as a result of the adoption of BC law), its Tobin’s Q can drop.

Consider a firm that has a book value of existing assets equal to 10 and market value of cash flows that can be generated from these assets as 15 . This firm also has a possibility of getting a project from a principal customer. This would require an investment of book value 4 and generate cash flows of present value of 6 to the firm.

Currently, the market assessment of the probability of getting the project as $50 \%$ (because there is exactly one competing supplier firm that is equally likely to get this project). Suppose at this time the state of incorporating of the firm passes a BC law. This makes the firm clearly more attractive from the perspective of the customer and it gets the project. It then undertakes the investment required for the project.

Let us analyze the Tobin's Q before and after the project is taken. Note that the standalone Tobin's Q of the project is 1.5 which is the same as the existing asset of the firm. (This assumption is made to point out that the argument does not rely on reducing marginal product of capital.)

The Tobin's $Q$ of the firm after the project is $(15+6) /(10+4)=1.5$

Before the firm takes the project and before the passage of BC law, the market value of the firm would incorporate the expected positive NPV from the possibility of getting the project in the future, which is $50 \% \times 2=1$. 
The Tobin's $Q$ at that point is $15+1 / 10=1.6$

Note that in the above example, Tobin's Q goes down after the passage of the BC law. It is important to the above argument that the supplier firm's takes on more investment after BC Law passage. We find that this is, in fact, true in the data. Table E9 in the Appendix shows that supplier firms invest have an asset growth that is higher by around 4\% points (actually, 3.6\% to 4.1\%) per year over the next four years after the law passage. 